4

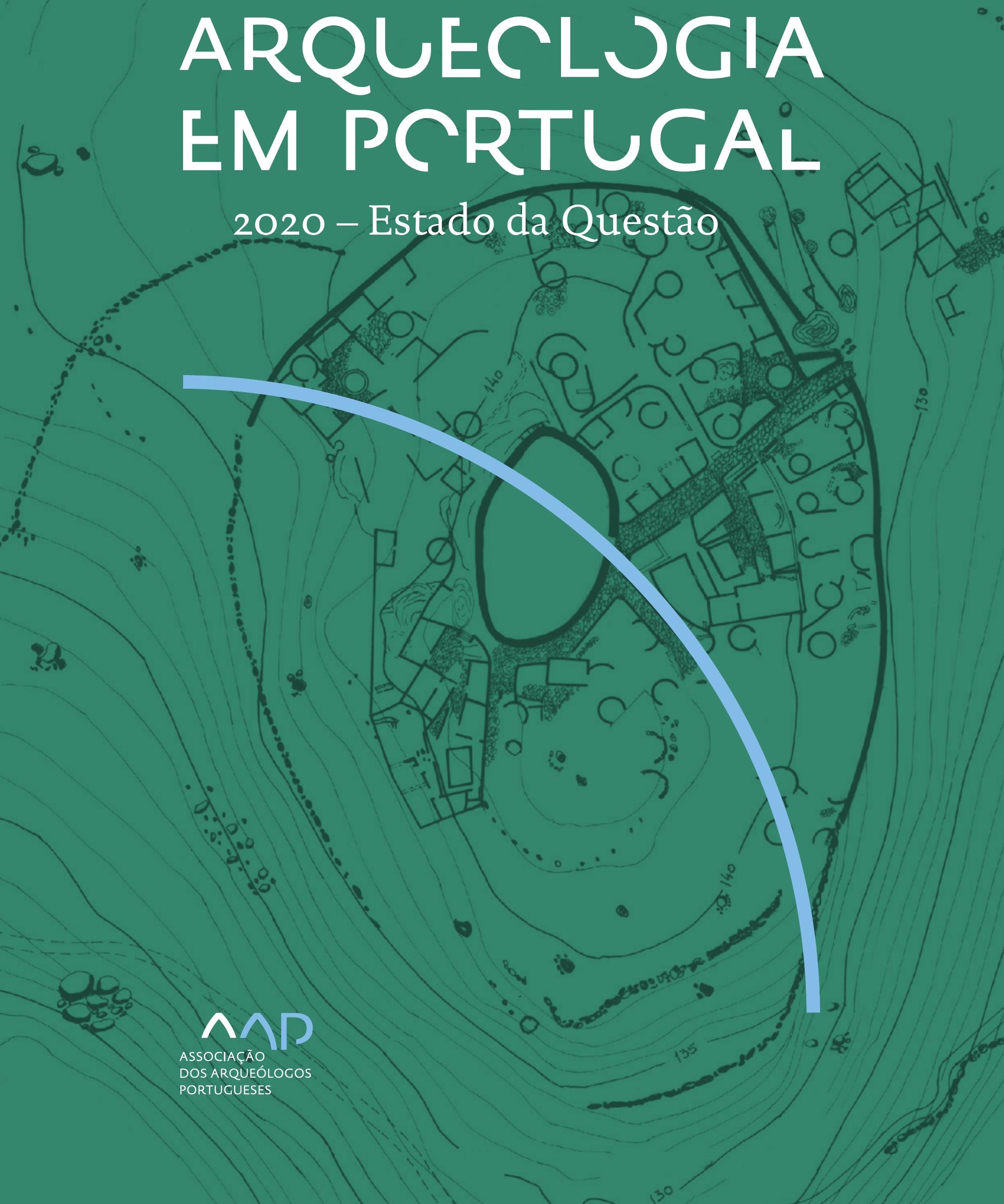


Coordenação editorial: José Morais Arnaud, César Neves e Andrea Martins Design gráfico: Flatland Design

AAP - ISBN: 978-972-9451-89-8

CITCEM - ISBN: 978-989-8970-25-1

Associação dos Arqueólogos Portugueses e CITCEM

Lisboa, 2020

O conteúdo dos artigos é da inteira responsabilidade dos autores. Sendo assim a Associação dos Arqueólogos Portugueses declina qualquer responsabilidade por eventuais equívocos ou questões de ordem ética e legal.

Desenho de capa:

Planta do castro de Monte Mozinho (Museu Municipal de Penafiel).

\section{$\hat{\wedge} \mathrm{P}$}

DOS ARQUEÓLOGOS PORTUGUESES

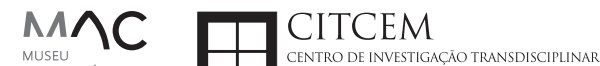
MUSEU
ARQUELLÓGICO
DO CARMO
U.PORTO

FLUP FACULDADE DE LETRAS
UNIVERSIDADE DO PORTO

Apoio

EC para a Ciência 


\section{Índice}

15 Prefácio

José Morais Arnaud

\section{Historiografia e Teoria}

17 Território, comunidade, memória e emoção: a contribuição da história da arqueologia (algumas primeiras e breves reflexões)

Ana Cristina Martins

25 Como descolonizar a arqueologia portuguesa?

Rui Gomes Coelho

41 Arqueologia e Modernidade: uma revisitação pessoal e breve de alguns aspetos da obra homónima de Julian Thomas de 2004

Vítor Oliveira Jorge

57 Dados para a História das Mulheres na Arqueologia portuguesa, dos finais do século XIX aos inícios do século XX: números, nomes e tabelas

Filipa Dimas / Mariana Diniz

73 Retractos da arqueologia portuguesa na imprensa: (in)visibilidades no feminino

Catarina Costeira / Elsa Luís

85 Arqueologia e Arqueólogos no Norte de Portugal Jacinta Bugalhão

101 Vieira Guimarães (1864-1939) e a arqueologia em Tomar: uma abordagem sobre o território e as gentes

João Amendoeira Peixoto / Ana Cristina Martins

115 Os memoráveis? A arqueologia algarvia na imprensa nacional e regional na presente centúria (2001-2019): características, visões do(s) passado(s) e a arqueologia

enquanto marca

Frederico Agosto / João Silva

129 A Evolução da Arqueologia Urbana e a Valorização Patrimonial no Barlavento Algarvio: Os casos de Portimão e Silves

Artur Mateus / Diogo Varandas / Rafael Boavida

\section{Gestão, Valorização e Salvaguarda do Património}

145 O Caderno Reivindicativo e as condições de trabalho em Arqueologia Miguel Rocha / Liliana Matias Carvalho / Regis Barbosa / Mauro Correia / Sara Simões / Jacinta Bugalhão / Sara Brito / Liliana Veríssimo Carvalho / Richard Peace / Pedro Peça / Cézer Santos

155 Os Estudos de Impacte Patrimonial como elemento para uma estratégia sustentável de minimização de impactes no âmbito de reconversões agrícolas Tiago do Pereiro

165 Salvaguarda de Património arqueológico em operações florestais: gestão e sensibilização Filipa Bragança / Gertrudes Zambujo / Sandra Lourenço / Belém Paiva / Carlos Banha / Frederico Tatá Regala / Helena Moura / Jacinta Bugalhão / João Marques / José Correia / Pedro Faria / Samuel Melro

179 Os valores do Património: uma investigação sobre os Sítios Pré-históricos de Arte Rupestre do Vale do Rio Côa e de Siega Verde José Paulo Francisco 
189 Conjugando recursos arqueológicos e naturais para potenciar as visitas ao Geoparque Litoral de Viana do Castelo (Noroeste de Portugal)

Hugo A. Sampaio / Ana M.S. Bettencourt / Susana Marinho / Ricardo Carvalhido

203 Áreas de Potencial Arqueológico na Região do Médio Tejo: Modelo Espacial Preditivo Rita Ferreira Anastácio / Ana Filipa Martins / Luiz Oosterbeek

223 Património Arqueológico e Gestão Territorial: O contributo da Arqueologia para a revisão do PDM de Avis

Ana Cristina Ribeiro

237 A coleção arqueológica do extinto Museu Municipal do Porto - Origens, Percursos e Estudos

Sónia Couto

251 Valpaços - uma nova carta arqueológica

Pedro Pereira / Maria de Fátima Casares Machado

263 Arqueologia na Cidade de Peniche

Adriano Constantino / Luís Rendeiro

273 Arqueologia Urbana: a cidade de Lagos como caso de Estudo Cátia Neto

285 Estratégias de promoção do património cultural subaquático nos Açores. O caso da ilha do Faial

José Luís Neto / José Bettencourt / Luís Borges / Pedro Parreira

297 Carta Arqueológica da Cidade Velha: Uma primeira abordagem

Jaylson Monteiro / Nireide Tavares / Sara da Veiga / Claudino Ramos / Edson Brito /

Carlos Carvalho / Francisco Moreira / Adalberto Tavares

311 Antropologia Virtual: novas metodologias para a análise morfológica e funcional Ricardo Miguel Godinho / Célia Gonçalves

\section{Didáctica da Arqueologia}

327 Como os projetos de Arqueologia podem contribuir para uma comunidade culturalmente mais consciente Alexandra Figueiredo / Claúdio Monteiro / Adolfo Silveira / Ricardo Lopes

337 Educação Patrimonial - Um cidadão esclarecido é um cidadão ativo! Ana Paula Almeida

351 A aproximação da Arqueologia à sala de aula: um caso de estudo no $3^{\circ}$ ciclo do Ensino Básico Luís Serrão Gil

363 Arqueologia 3.o - Pensar e comunicar a Arqueologia para um futuro sustentável Mónica Rolo

377 “Conversa de Arqueólogos" - Divulgar a Arqueologia em tempos de Pandemia Diogo Teixeira Dias

389 Escola Profissional de Arqueologia: desafios e oportunidades Susana Nunes / Dulcineia Pinto / Júlia Silva / Ana Mascarenhas

399 Os Museus de Arqueologia e os Jovens: a oferta educativa para o público adolescente Beatriz Correia Barata / Leonor Medeiros

411 O museu universitário como mediador entre a ciência e a sociedade: o exemplo da secção de arqueologia no Museu de História Natural e da Ciência da Universidade do Porto (MHNC-UP)

Rita Gaspar 
421 Museu de Lanifícios: Real Fábrica de Panos. Atividades no âmbito da Arqueologia Beatriz Correia Barata / Rita Salvado

427 Arqueologia Pública e o caso da localidade da Mata (Torres Novas) Cláudia Manso / Ana Rita Ferreira / Cristiana Ferreira / Vanessa Cardoso Antunes

431 Do sítio arqueológico ao museu: um percurso (também) didático Lídia Fernandes

447 Estão todos convidados para a Festa! E para dançar também... O projecto do Serviço Educativo do Museu Arqueológico do Carmo na $5^{\underline{a}}$ Edição da Festa da Arqueologia Rita Pires dos Santos

459 O “Clã de Carenque”, um projeto didático de arqueologia Eduardo Gonzalez Rocha

469 Mediação cultural: peixe que puxa carroça nas Ruínas Romanas de Troia Inês Vaz Pinto / Ana Patrícia Magalhães / Patrícia Brum / Filipa Santos

481 Didática Arqueológica, experiências do Projeto Mértola Vila Museu Maria de Fátima Palma / Clara Rodrigues / Susana Gómez / Lígia Rafael

\section{Arte Rupestre}

497 Os inventários de arte rupestre em Portugal Mila Simões de Abreu

513 O projeto FIRST-ART - conservação, documentação e gestão das primeiras manifestações de arte rupestre no Sudoeste da Península Ibérica: as grutas do Escoural e Maltravieso Sara Garcês / Hipólito Collado / José Julio García Arranz / Luiz Oosterbeek / António Carlos Silva / Pierluigi Rosina / Hugo Gomes / Anabela Borralheiro Pereira / George Nash / Esmeralda Gomes / Nelson Almeida / Carlos Carpetudo

523 Trabalhos de documentação de arte paleolítica realizados no âmbito do projeto PalæoCôa André Tomás Santos / António Fernando Barbosa / Luís Luís / Marcelo Silvestre / Thierry Aubry

537 Imagens fantasmagóricas, silhuetas elusivas: as figuras humanas na arte do Paleolítico Superior da região do Côa Mário Reis

$55^{1}$ Os motivos zoomórficos representados nas placas de tear de Vila Nova de São Pedro (Azambuja, Portugal) Andrea Martins / César Neves / José M. Arnaud / Mariana Diniz

571 Arte Rupestre do Monte de Góios (Lanhelas, Caminha). Síntese dos resultados dos trabalhos efectuados em 2007-2009 Mário Varela Gomes

599 Gravuras rupestres de barquiformes no Monte de S. Romão, Guimarães, Noroeste de Portugal Daniela Cardoso

613 Círculos segmentados gravados na Bacia do Rio Lima (Noroeste de Portugal): contributos para o seu estudo Diogo Marinho / Ana M.S. Bettencourt / Hugo Aluai Sampaio

631 Equídeos gravados no curso inferior do Rio Mouro, Monção (NW Portugal). Análise preliminar Coutinho, L.M. / Bettencourt, A.M.S / Sampaio, Hugo A.S

645 Paletas na Arte Rupestre do Noroeste de Portugal. Inventário preliminar Bruna Sousa Afonso / Ana M. S. Bettencourt / Hugo A. Sampaio 


\section{Pré-História}

661 O projeto Miño/Minho: balanço de quatro anos de trabalhos arqueológicos Sérgio Monteiro-Rodrigues / João Pedro Cunha-Ribeiro / Eduardo Méndez-Quintas / Carlos Ferreira / Pedro Xavier / José Meireles / Alberto Gomes / Manuel Santonja / Alfredo Pérez-González

677 A ocupação paleolítica da margem esquerda do Baixo Minho: a indústria lítica do sítio de Pedreiras 2 (Monção, Portugal) e a sua integração no contexto regional Carlos Ferreira / João Pedro Cunha-Ribeiro / Sérgio Monteiro-Rodrigues / Eduardo Méndez-Quintas / Pedro Xavier / José Meireles / Alberto Gomes / Manuel Santonja / Alfredo Pérez-González

693 O sítio acheulense do Plistocénico médio da Gruta da Aroeira Joan Daura / Montserrat Sanz / Filipa Rodrigues / Pedro Souto / João Zilhão

703 As sociedades neandertais no Barlavento algarvio: modelos preditivos com recurso aos SIG

Daniela Maio

715 A utilização de quartzo durante o Paleolítico Superior no território dos vales dos rios Vouga e Côa

Cristina Gameiro / Thierry Aubry / Bárbara Costa / Sérgio Gomes / Luís Luís / Carmen Manzano / André Tomás Santos

733 Uma perspetiva diacrónica da ocupação do concheiro do Cabeço da Amoreira (Muge, Portugal) a partir da tecnologia lítica Joana Belmiro / João Cascalheira / Célia Gonçalves

745 Novos dados sobre a Pré-história Antiga no concelho de Palmela. A intervenção arqueológica no sítio do Poceirão I

Michelle Teixeira Santos

757 Problemas em torno de Datas Absolutas Pré-Históricas no Norte do Alentejo Jorge de Oliveira

771 Povoamento pré-histórico nas áreas montanhosas do NO de Portugal: o Abrigo 1 de Vale de Cerdeira Pedro Xavier / José Meireles / Carlos Alves

783 Apreciação do povoamento do Neolítico Inicial na Baixa Bacia do Douro. A Lavra I (Serra da Aboboreira) como caso de estudo Maria de Jesus Sanches

797 O Processo de Neolitização na Plataforma do Mondego: os dados do Sector C do Outeiro dos Castelos de Beijós (Carregal do Sal)

João Carlos de Senna-Martinez / José Manuel Quintã Ventura / Andreia Carvalho / Cíntia Maurício

823 Novos trabalhos na Lapa da Bugalheira (Almonda, Torres Novas) Filipa Rodrigues / Pedro Souto / Artur Ferreira / Alexandre Varanda / Luís Gomes / Helena Gomes / João Zilhão

837 A pedra polida e afeiçoada do sítio do Neolítico médio da Moita do Ourives (Benavente, Portugal)

César Neves

857 Casal do Outeiro (Encarnação, Mafra): novos contributos para o conhecimento do povoamento do Neolítico final na Península de Lisboa.

Cátia Delicado / Carlos Maneira e Costa / Marta Miranda / Ana Catarina Sousa

873 Stresse infantil, morbilidade e mortalidade no sítio arqueológico do Neolítico Final/ Calcolítico ( $4^{\circ}$ e $3^{\circ}$ milénio a.C.) do Monte do Carrascal 2 (Ferreira do Alentejo, Beja) Liliana Matias de Carvalho / Sofia N. Wasterlain 
885 Come together: O Conjunto Megalítico das Motas (Monção, Viana do Castelo) e as expressões Campaniformes do Alto Minho Ana Catarina Basílio / Rui Ramos

899 Trabalhos arqueológicos no sítio Calcolítico da Pedreira do Poio Carla Magalhães / João Muralha / Mário Reis / António Batarda Fernandes

913 O sítio arqueológico de Castanheiro do Vento. Da arquitectura do sítio à arquitectura de um território João Muralha Cardoso

925 Estudo zooarqueológico das faunas do Calcolítico final de Vila Nova de São Pedro (Azambuja, Portugal): Campanhas de 2017 e 2018 Cleia Detry / Ana Catarina Francisco / Mariana Diniz / Andrea Martins / César Neves / José Morais Arnaud

943 As faunas depositadas no Museu Arqueológico do Carmo provenientes de Vila Nova de São Pedro (Azambuja): as campanhas de 1937 a 1967 Ana Catarina Francisco / Cleia Detry / César Neves / Andrea Martins / Mariana Diniz / José Morais Arnaud

959 Análise funcional de material lítico em sílex do castro de Vila Nova de S. Pedro (Azambuja, Portugal): uma primeira abordagem Rafael Lima

971 O recinto da Folha do Ouro 1 (Serpa) no contexto dos recintos de fossos calcolíticos alentejanos

António Carlos Valera / Tiago do Pereiro / Pedro Valério / António M. Monge Soares

\section{Proto-História}

987 Produção de sal marinho na Idade do Bronze do noroeste Português. Alguns dados para uma reflexão

Ana M. S. Bettencourt / Sara Luz / Nuno Oliveira / Pedro P. Simões / Maria Isabel C. Alves / Emílio Abad-Vidal

1001 A estátua-menir do Pedrão ou de São Bartolomeu do Mar (Esposende, noroeste de Portugal) no contexto arqueológico da fachada costeira de entre os rios Neiva e Cávado Ana M. S. Bettencourt / Manuel Santos-Estévez / Pedro Pimenta Simões / Luís Gonçalves

1015 O Castro do Muro (Vandoma/Baltar, Paredes) - notas para uma biografia de ocupação da Idade do Bronze à Idade Média

Maria Antónia D. Silva / Ana M. S. Bettencourt / António Manuel S. P. Silva / Natália Félix

1031 Do Bronze Final à Idade Média - continuidades e hiatos na ocupação de Povoados em Oliveira de Azeméis João Tiago Tavares / Adriaan de Man

1041 As faunas do final da Idade do Bronze no Sul de Portugal: leituras desde o Outeiro do Circo (Beja)

Nelson J. Almeida / Íris Dias / Cleia Detry / Eduardo Porfírio / Miguel Serra

1055 A Espada do Monte das Oliveiras (Serpa) - uma arma do Bronze Pleno do Sudoeste Rui M. G. Monge Soares / Pedro Valério / Mariana Nabais / António M. Monge Soares

1065 São Julião da Branca (Albergaria-a-Velha) - Investigação e valorização de um povoado do Bronze Final

António Manuel S. P. Silva / Paulo A. P. Lemos / Sara Almeida e Silva / Edite Martins de Sá

1083 Do castro de S. João ao Mosteiro de Santa Clara: notícia de uma intervenção arqueológica, em Vila do Conde Rui Pinheiro 
1095 O castro de Ovil (Espinho), um quarto de século de investigação - resultados e questões em aberto

Jorge Fernando Salvador / António Manuel S. P. Silva

1111 O Castro de Salreu (Estarreja), um povoado proto-histórico no litoral do Entre Douro e Vouga

Sara Almeida e Silva / António Manuel S. P. Silva / Paulo A. P. Lemos / Edite Martins de Sá

1127 Castro de Nossa Senhora das Necessidades (Sernancelhe): uma primeira análise artefactual Telma Susana O. Ribeiro

${ }_{1141}$ A cividade de Bagunte. O estado atual da investigação Pedro Brochado de Almeida

1153 Zoomorfos na cerâmica da Idade do Ferro no NW Peninsular: inventário, cronologias e significado Nuno Oliveira / Cristina Seoane

1163 Vasos gregos em Portugal: diferentes maneiras de contar a história do intercâmbio cultural na Idade do Ferro

Daniela Ferreira

1175 Os exotica da necrópole da Idade do Ferro do Olival do Senhor dos Mártires (Alcácer do Sal) no seu contexto regional

Francisco B. Gomes

\section{Antiguidade Clássica e Tardia}

1191 O uso de madeira como combustível no sítio da Quinta de Crestelos (Baixo Sabor): da Idade do Ferro à Romanização Filipe Vaz / João Tereso / Sérgio Simões Pereira / José Sastre / Javier Larrazabal Galarza / Susana Cosme / José António Pereira / Israel Espi

1207 Cultivos de Época Romana no Baixo Sabor: continuidade em tempos de mudança? João Pedro Tereso / Sérgio Simões Pereira / Filipe Santos / Luís Seabra / Filipe Vaz

1221 A casa romana na Hispânia: aplicação dos modelos itálicos nas províncias ibéricas Fernanda Magalhães / Diego Machado / Manuela Martins

1235 As pinturas murais romanas da Rua General Sousa Machado, n. ${ }^{5}$ 1, Chaves José Carvalho

1243 Trás do Castelo (Vale de Mir, Pegarinhos, Alijó) - Uma exploração agrícola romana do Douro

Tony Silvino / Pedro Pereira

1255 A sequência de ocupação no quadrante sudeste de Bracara Augusta: as transformações de uma unidade doméstica Lara Fernandes / Manuela Martins

1263 Os Mosaicos com decoração geométrica e geométrico-vegetalista dos sítios arqueológicos da área do Conuentus Bracaraugustanus. Novas abordagens quanto à conservação, restauro, decoração e datação Maria de Fátima Abraços / Licínia Wrench

1277 “Casa Romana” do Castro de São Domingos (Cristelos, Lousada): Escavação, Estudo e Musealização Paulo André de P. Lemos

1291 A arqueobotânica no Castro de Guifões (Matosinhos, Noroeste de Portugal): O primeiro estudo carpológico

Luís Seabra / Andreia Arezes / Catarina Magalhães / José Varela / João Pedro Tereso 
1305 Um Horreum Augustano na Foz do Douro (Monte do Castelo de Gaia, Vila Nova de Gaia) Rui Ramos

1311 Ponderais romanos na Lusitânia: padrões, formas, materiais e contextos de utilização Diego Barrios Rodríguez

1323 Um almofariz centro-itálico na foz do Mondego

Marco Penajoia

1335 Estruturas romanas de Carnide - Lisboa Luísa Batalha / Mário Monteiro / Guilherme Cardoso

1347 O contexto funerário do sector da "necrópole NO" da Rua das Portas de S. Antão (Lisboa): o espaço, os artefactos, os indivíduos e a sua interconectividade na interpretação do passado Sílvia Loja, José Carlos Quaresma, Nelson Cabaço, Marina Lourenço, Sílvia Casimiro, Rodrigo Banha da Silva, Francisca Alves-Cardoso

${ }_{1361}$ Povoamento em época Romana na Amadora - resultados de um projeto pluridisciplinar Gisela Encarnação / Vanessa Dias

1371 A Arquitectura Residencial em Mirobriga (Santiago do Cacém): contributo a partir de um estudo de caso Filipe Sousa / Catarina Felício

${ }_{1385}$ O fim do ciclo. Saneamento e gestão de resíduos nos edifícios termais de Mirobriga (Santiago do Cacém)

Catarina Felício / Filipe Sousa

1399 Balsa, Topografia e Urbanismo de uma Cidade Portuária Vítor Silva Dias / João Pedro Bernardes / Celso Candeias / Cristina Tété Garcia

1413 No Largo das Mouras Velhas em Faro (2017): novas evidências da necrópole norte de Ossonoba e da sua ocupação medieval Ricardo Costeira da Silva / Paulo Botelho / Fernando Santos / Liliana Nunes

1429 Instrumentos de pesca recuperados numa fábrica de salga em Ossonoba (Faro) Inês Rasteiro / Ricardo Costeira da Silva / Paulo Botelho

1439 A Necrópole Romana do Eirô, Duas Igrejas (Penafiel): intervenção arqueológica de 2016 Laura Sousa / Teresa Soeiro

1457 Ritual, descarte ou afetividade? A presença de Canis lupus familiaris na Necrópole Noroeste de Olisipo (Lisboa)

Beatriz Calapez Santos / Sofia Simões Pereira / Rodrigo Banha da Silva / Sílvia Casimiro / Cleia Detry / Francisca Alves Cardoso

1467 Dinâmicas económicas em Bracara na Antiguidade Tardia Diego Machado / Manuela Martins / Fernanda Magalhães / Natália Botica

1479 Cerâmicas e Vidros da Antiguidade Tardia do Edifício sob a Igreja do Bom Jesus (Vila Nova de Gaia) Joaquim Filipe Ramos

1493 Novos contributos para a topografia histórica de Mértola no período romano e na Antiguidade Tardia Virgílio Lopes

\section{8. Época Medieval}

1511 Cerâmicas islâmicas no Garb setentrional "português": algumas evidências e incógnitas Constança dos Santos / Helena Catarino / Susana Gómez / Maria José Gonçalves / Isabel Inácio / Gonçalo Lopes / Jacinta Bugalhão / Sandra Cavaco / Jaquelina Covaneiro / Isabel Cristina Fernandes / Ana Sofia Gomes 
1525 Contributo para o conhecimento da cosmética islâmica, em Silves, durante a Idade Média Rosa Varela Gomes

1537 Yábura e o seu território - uma análise histórico-arqueológica de Évora entre os séculos VIII-XII José Rui Santos

1547 A encosta sul do Castelo de Palmela - resultados preliminares da escavação arqueológica Luís Filipe Pereira / Michelle Teixeira Santos

1559 A igreja de São Lourenço (Mouraria, Lisboa): um conjunto de silos e de cerâmica medieval islâmica

Andreia Filipa Moreira Rodrigues

1571 O registo material de movimentações populacionais no Médio Tejo, durante os séculos XII-XIII. Dois casos de "sunken featured buildings", nos concelhos de Cartaxo e Torres Novas Marco Liberato / Helena Santos / Nuno Santos

1585 O nordeste transmontano nos alvores da Idade média. Notas para reflexão Ana Maria da Costa Oliveira

1601 Sepulturas escavadas na rocha do Norte de Portugal e do Vale do Douro: primeiros resultados do Projecto SER-NPVD

Mário Jorge Barroca / César Guedes / Andreia Arezes / Ana Maria Oliveira

1619 "Portucalem Castrum Novum" entre o Mediterrâneo e o Atlântico: o estudo dos materiais cerâmicos alto-medievais do arqueossítio da rua de D. Hugo, nํ. 5 (Porto) João Luís Veloso

1627 A Alta Idade Média na fronteira de Lafões: notas preliminares sobre a Arqueologia no Concelho de Vouzela

Manuel Luís Real / Catarina Tente

1641 Um conjunto cerâmico medieval fora de portas: um breve testemunho aveirense Susana Temudo

${ }_{1651}$ Os Lóios do Porto: uma perspetiva integrada no panorama funerário da Baixa Idade Média à Época Moderna em meios urbanos em Portugal

Ana Lema Seabra

1659 O Caminho Português Interior de Santiago como eixo viário na Idade Média Pedro Azevedo

1665 Morfologia Urbana: Um exercício em torno do Castelo de Ourém André Donas-Botto / Jaqueline Pereira

1677 Intervenção arqueológica na Rua Marquês de Pombal/Largo do Espírito Santo (Bucelas, Loures)

Florbela Estêvão / Nathalie Antunes-Ferreira / Dário Ramos Neves / Inês Lisboa

1691 O Cemitério Medieval do Poço do Borratém e a espacialidade funerária na cidade de Lisboa Inês Belém / Vanessa Filipe / Vasco Noronha Vieira / Sónia Ferro / Rodrigo Banha da Silva

1705 Um Espaço Funerário Conventual do séc. XV em Lisboa: o caso do Convento de São Domingos da Cidade Sérgio Pedroso / Sílvia Casimiro / Rodrigo Banha da Silva / Francisca Alves Cardoso

\section{9. Época Moderna e Contemporânea}

1721 Arqueologia Moderna em Portugal: algumas reflexões críticas em torno da quantificação de conjuntos cerâmicos e suas inferências históricas e antropológicas Rodrigo Banha da Silva / André Bargão / Sara da Cruz Ferreira

1733 Faianças de dois contextos entre os finais do século XVI e XVIII do Palácio dos Condes de Penafiel, Lisboa

Martim Lopes / Tomás Mesquita 
1747 Um perfil de consumo do século XVIII na foz do Tejo: O caso do Mercado da Ribeira, Lisboa Sara da Cruz Ferreira / Rodrigo Banha da Silva / André Bargão

1761 Os Cachimbos dos Séculos XVII e XVIII do Palácio Mesquitela e Convento dos Inglesinhos (Lisboa)

Inês Simão / Marina Pinto / João Pimenta / Sara da Cruz Ferreira / André Bargão / Rodrigo Banha da Silva

1775 "Tomar os fumos da erua que chamão em Portugal erua sancta». Estudo de Cachimbos provenientes da Rua do Terreiro do Trigo, Lisboa

Miguel Martins de Sousa / José Pedro Henriques / Vanessa Galiza Filipe

1787 Cachimbos de Barro Caulínitico da Sé da Cidade Velha (República de Cabo Verde)

Rodrigo Banha da Silva / João Pimenta / Clementino Amaro

1801 Algumas considerações sobre espólio não cerâmico recuperado no Largo de Jesus (Lisboa) Carlos Boavida

1815 Adereços de vidro, dos séculos XVI-XVIII, procedentes do antigo Convento de Santana de Lisboa (anéis, braceletes e contas)

Joana Gonçalves / Rosa Varela Gomes / Mário Varela Gomes

1837 Da ostentação, luxo e poder à simplicidade do uso quotidiano: arqueologia e simbologia de joias e adornos da Idade Moderna Portuguesa Jéssica Iglésias

1849 Os amuletos em Portugal - dos objetos às superstições: o coral vermelho Alexandra Vieira

1865 Cerâmicas de Vila Franca de Xira nos séculos XV e XVI Eva Pires

1879 «Não passa por teu o que me pertence». Marcas de individualização associadas a faianças do Convento de Nossa Senhora de Aracoeli, Alcácer do Sal Catarina Parreira / Íris Fragoso / Miguel Martins de Sousa

1891 Cerâmica de Leiria: alguns focos de produção

Jaqueline Pereira / André Donas-Botto

1901 Os Fornos na Rua da Biquinha, em Óbidos Hugo Silva / Filipe Oliveira

1909 A casa de Pêro Fernandes, contador dos contos de D. Manuel I: o sítio arqueológico da Silha do Alferes, Seixal (século XVI) Mariana Nunes Ferreira

1921 O Alto da Vigia (Sintra) e a vigilância e defesa da costa Alexandre Gonçalves / Sandra Santos

1937 O contexto da torre sineira da Igreja de Santa Maria de Loures Paulo Calaveira / Martim Lopes

1949 A Necrópole do Hospital Militar do Castelo de São Jorge e as práticas funerárias na Lisboa de Época Moderna Susana Henriques / Liliana Matias de Carvalho / Ana Amarante / Sofia N. Wasterlain

1963 SAND - Sarilhos Grandes Entre dois Mundos: o adro da Igreja e a Paleobiologia dos ossos humanos recuperados

Paula Alves Pereira / Roger Lee Jesus / Bruno M. Magalhães

1975 Expansão urbana da vila de Cascais no século XVII e XVIII: a intervenção arqueológica na Rua da Vitória no 15 a 17

Tiago Pereira / Vanessa Filipe

1987 Novos dados para o conhecimento do Urbanismo de Faro em época Moderna Ana Rosa 
1995 Um exemplo de Arqueologia Urbana em Alcoutim: o Antigo Edifício dos CTT Marco Fernandes / Marta Dias / Alexandra Gradim / Virgílio Lopes / Susana Gómez Martínez

2007 Palácio dos Ferrazes (Rua das Flores/Rua da Vitória, Porto): a cocheira de Domingos Oliveira Maia

Francisco Raimundo

2021 As muitas vidas de um edifício urbano: História, Arqueologia e Antropologia no antigo Recreatório Paroquial de Penafiel Helena Bernardo / Jorge Sampaio / Marta Borges

2035 O convento de Nossa Senhora da Esperança de Ponta Delgada: o contributo da arqueologia para o conhecimento de um monumento identitário João Gonçalves Araújo / N’Zinga Oliveira

2047 Arqueologia na ilha do Corvo... em busca da capela de Nossa Senhora do Rosário Tânia Manuel Casimiro / José Luís Neto / Luís Borges / Pedro Parreira

2059 Perdidos à vista da Costa. Trabalhos arqueológicos subaquáticos na Barra do Tejo Jorge Freire / José Bettencourt / Augusto Salgado

2071 Arqueologia marítima em Cabo Verde: enquadramento e primeiros resultados do projecto CONCHA

José Bettencourt / Adilson Dias / Carlos Lima / Christelle Chouzenoux / Cristóvão Fonseca / Dúnia Pereira / Gonçalo Lopes / Inês Coelho / Jaylson Monteiro / José Lima / Maria Eugénia Alves / Patrícia Carvalho / Tiago Silva

2085 Trabalhos arqueológicos na Cidade Velha (Ribeira Grande de Santiago, Cabo Verde): reflexões sobre um projecto de investigação e divulgação patrimonial André Teixeira / Jaylson Monteiro / Mariana Mateus / Nireide Tavares / Cristovão Fonseca / Gonçalo C. Lopes / Joana Bento Torres / Dúnia Pereira / André Bargão / Aurélie Mayer / Bruno Zélie / Carlos Lima / Christelle Chouzenoux / Inês Henriques / Inês Pinto Coelho / José Lima / Patrícia Carvalho / Tiago Silva

2103 A antiga fortificação de Quelba / Khor Kalba (E.A.U.). Resultados de quatro campanhas de escavações, problemáticas e perspectivas futuras Rui Carita / Rosa Varela Gomes / Mário Varela Gomes / Kamyar Kamyad

2123 Colónias para homens novos: arqueologia da colonização agrária fascista no noroeste ibérico Xurxo Ayán Vila / José Mạ . Señorán Martín 


\title{
O CASTRO DE SALREU (ESTARREJA), UM POVOADO PROTO-HISTÓRICO NO LITORAL DO ENTRE DOURO E VOUGA
}

Sara Almeida E Silva ${ }^{1}$, António Manuel S. P. Silva ${ }^{2}$, Paulo A. P. Lemos ${ }^{3}$, Edite Martins de Sá ${ }^{4}$

\begin{abstract}
RESUMO
O Castro de Salreu, localizado no concelho de Estarreja (Aveiro, centro-norte de Portugal), é um dos povoados proto-históricos mais litorais do Entre Douro e Vouga, usufruindo de implantação privilegiada sobre um meandro do Antuã. O sítio tem vindo a ser alvo, nos últimos anos, de trabalhos arqueológicos que colocaram a descoberto estruturas em duas áreas principais, uma de cariz habitacional e, a outra, relacionada com a estrutura defensiva e delimitadora do espaço. As cinco campanhas realizadas permitiram a recolha de mais de 3500 fragmentos cerâmicos, alguns líticos, uma placa gravada, escassos metais e um conjunto de mais de duas dezenas de contas em pasta de vidro. Propõe-se que a sua ocupação tenha ocorrido entre os séculos IV/III a.C. e a mudança da Era.
\end{abstract}

Palavras-chave: Idade do Ferro, "Cultura castreja», Entre Douro e Vouga, Centro-Norte de Portugal.

\begin{abstract}
The Castro of Salreu, located in the municipality of Estarreja (Aveiro, center-north of Portugal), is one of the most coastal proto-historic settlements of the region between Douro and Vouga rivers, enjoying a privileged location on a meander of the river Antuã. The site has been the target, in recent years, of archaeological works that uncovered structures in two main areas, one of a housing nature and the other, corresponding to the defensive and delimiting structure of space. The five archaeological campaigns carried out allowed the collection of more than 35, ooo ceramic fragments, some lithic artifacts, an engraved plaque, few metal objects and a set of more than two dozen glass paste beads.

It is proposed that their occupation occurred between the $4^{\text {th }} / 3^{\text {rd }}$ centuries BC and the change of the Age. Keywords: Iron Age, Castros' Culture, Douro-Vouga region, Center-North of Portugal.
\end{abstract}

\section{INTRODUÇÃO}

Alvo de intervenção arqueológica pela primeira vez em 2011, o Castro de Salreu conta já com cinco campanhas de trabalhos, desenvolvidas no âmbito dos projetos deinvestigação PROBA (2011-2015) (SILVA, PEREIRA, LEMOS, 2012; SILVA $\&$ allii, 2016a) e PROBA ${ }^{+2}$ (2016-2018) (SILVA $\&$ alii, 2016b; SILVA $\&$ alii, 2017a; ALMEIDA E SILVA \& alii, 2018; SILVA $\&$ alii, no prelo), centrados no estudo da proto-história da bacia do rio Antuã, um afluente do
Vouga, e ARQ-EDOV (2019-2022) - Arqueologia da Idade do Ferro no Entre Douro e Vouga Atlântico (SILVA $\mathbb{Z}$ alii, 2019). Estes projetos de investigação são coordenados pelo Centro de Arqueologia de Arouca, sendo o financiamento assegurado pelas autarquias parceiras, neste caso pelo Município de Estarreja e Junta de Freguesia de Salreu.

O Castro de Salreu, um dos povoados proto-históricos litorais da região do Entre Douro e Vouga, constitui um exemplo da continuidade, nas regiões a sul do rio Douro, da tradicionalmente designada

\footnotetext{
1. saralmeidasilva@gmail.com; Centro de Arqueologia de Arouca

2. amspsilva@hotmail.com; Centro de Arqueologia de Arouca; Investigador do CITCEM

3.paplemos@gmail.com; Centro de Arqueologia de Arouca

4. editesa@gmail.com; Centro de Arqueologia de Arouca
} 
"cultura castreja" do noroeste ibérico. O presente texto sintetiza os resultados dos trabalhos efetuados e dá conta das principais problemáticas em investigação neste sítio arqueológico.

\section{LOCALIZAÇÃO, ENQUADRAMENTO E CARACTERIZAÇÃO GERAL DO POVOADO}

Localizado na freguesia de Salreu, concelho de Estarreja, distrito de Aveiro (Figura 1), o sítio apresenta uma implantação topográfica muito comum entre os povoados desta natureza, localizando-se sobre uma pequena colina, num meandro do rio Antuã, com escarpas declivosas por todos os sectores, exceto o voltando a nascente, através do qual se conecta ao pequeno lugar habitado que preserva ainda o topónimo Crasto. O castro apresenta uma altitude média de 54 metros, tendo como coordenadas do ponto central $40^{\circ} 45^{\prime} 42,50^{\prime \prime}$ N.; o 8 32 ' 57,64” O. (WGS84).

Hoje aparentemente mais distante do Atlântico, o Castro de Salreu estaria bem mais próximo do mar na Idade do Ferro, em virtude da evolução da linha costeira e das alterações significativas que a região sofreu relacionadas com a formação da laguna de Aveiro. Nessa época, o rio Antuã, com uma foz mais aberta queaatual, desaguaria diretamenteno Oceano e o povoado seria praticamente litoral, sendo certamente acessível a embarcações que ali chegassem por essa via (SILVA, PEREIRA, LEMOS, 2012: 49-50; SILVA \& alii, 2019: 27).

Do ponto de vista geológico, a estação implanta-se sobre xistos cloríticos, sericíticos e moscovíticos que se prolongam, no sentido NO.-SE., pela faixa litoral desde Espinho a Estarreja. Estas rochas sedimentares integram o tradicionalmente designado Complexo Xisto-Grauváquico ante-Ordovícico e séries metamórficas derivadas, demarcando-se no vale do Antuã pela presença frequente de lentículas de quartzo intercaladas, sendo, maioritariamente, coberto por depósitos de praia localizados na ordem dos 60 a $70 \mathrm{~m}$ de altitude, datáveis do Plio-Pleistocénico (TEIXEIRA, 1963: 10-1; REAL, 1987: 23).

O povoado ocupa uma área estimada de dois hectares e organiza-se, topograficamente, em três plataformas e respetivos taludes (Figura 2), encontrando-se a superior arrasada totalmente pelo plantio mecânico de eucaliptal. Nas restantes plataformas ocorreram também significativas movimentações de terra, na sequência de ações similares, o que prejudicou sobremaneira a preservação dos vestígios arqueológicos.

\section{A INVESTIGAÇÃO REALIZADA}

Ao longo do século XX, o "Castro de Salreu» foi mencionado quer por estudiosos locais, quer mesmo em inventários arqueológicos, com base, essencialmente, no microtopónimo sugestivo, sem que fosse apontada sequer a sua localização exata (SILVA, 1986: 105; SILVA, PEREIRA, LEMOS, 2012: 52-3). A sua correta identificação e primeira caracterização geral (SILVA, 1993; 1994: 53; 2002) abriram caminho ao estudo do povoado, que todavia só foi iniciado em 2011 (SILVA, PEREIRA, LEMOS, 2012). As primeiras sondagens, realizadas naquele ano, confirmaram a natureza e cronologia da estação arqueológica e evidenciaram a alteração profunda dos depósitos na plataforma superior, decorrente do plantio mecanizado. Já a intervenção efetuada no talude da plataforma intermédia propiciou a descoberta de ténues estruturas antigas,constituídas por restos de alinhamentos pétreos correspondentes a, pelo menos, duas fases distintas de construção e interpretados como muretes de delimitação e contenção da própria plataforma (SILVA, PEREIRA, LEMOS, 2012: 64-71).

Os trabalhos tiveram entretanto de ser interrompidos, por falta de financiamento, tendo sido retomados em 2016. Nessa segunda campanha privilegiou-se a escavação de uma área limítrofe à intervencionada em 2011, o designado sector A, o que viria a resultar na identificação de uma área habitacional, onde, com a continuidade dos trabalhos se pôs a descoberto o fundo de uma pequena cabana de planta ovalada.

Entre os anos de 2016 e 2018 foram feitas sondagens em outros pontos do povoado, nomeadamente na sua plataforma inferior, que forneceram bastante espólio arqueológico, não tendo revelado estruturas de realce (SILVA \& alii, 2016b; 2017a; 2019). Foi entretanto localizado um troço da estrutura de delimitação do povoado, que tem sido objeto de escavações desde 2017 (sector K) e à qual adiante se fará referência mais detalhada.

Um dos elementos que não pôde ainda contar com trabalhos específicos é o sistema de fossos, que complementavam a organização defensiva do povoado. De um, aberto em depressão natural resultante da presença de pequenas linhas de água tributárias do Antuã e muito assoreado, há vestígios na encosta a nordeste; na vertente sudeste, aparentemente delineado na continuidade do terceiro talude, vêem-se 
também traços de estrutura similar (SILVA, 1994: 53; 2002; SILVA, PEREIRA, LEMOS, 2012: 53).

\section{SECTOR A - UMA CABANA DA IDADE DO FERRO}

Localizado na segunda plataforma do povoado (Figura 2), este sector foi alvo de escavação em sucessivas campanhas, uma vez que os resultados obtidos iam ditando a necessidade de alargamentos da área escavada. Todavia, a zona de talude desta plataforma apresentava uma possança estratigráfica significativa, em consequência dos trabalhos de movimentações de terras ali ocorridos em épocas mais recentes. Se, por um lado, a grande profundidade dos vestígios, identificados a mais de dois metros de profundidade, poderá ter facilitado a sua preservação, por outro dificultou de forma notória o desenrolar dos trabalhos.

Neste sector foi identificada aquela que é, até à data, a única estrutura habitacional do povoado. Encontrava-se, pese embora a profundidade a que se achava, bastante mal preservada. Pôde determinar-se, porém, a planta de um espaço doméstico de contorno ovalado, que poderá medir, a admitirmos alguma regularidade, cerca de 4,30 $\mathrm{m}$ por 3,60 metros (Figuras 3 e 4). Esta cabana, se assim lhe podemos chamar, foi implantada no maciço rochoso natural, expressamente talhado para o efeito, tendo sido mesmo aberto um pequeno canal, provavelmente destinado ao escoamento de águas, junto ao limite sul da estrutura (SILVA \& alii, 2016b: 46-8; 2017a: 23-4; ALMEIDA E SILVA \& alii, 2018: 37-9).

A identificação dos negativos de assentamento das ombreiras da porta, orientada a poente, indicia que a dimensão média do muro da construção - de que resta apenas um pequeno tramo-rondaria os o,3om, o que configura um muro algo estreito, sendo talvez difícil que permitisse sustentar uma edificação exclusivamente em pedra, pelo que admitimos a possibilidade de um aparelho construtivo misto, fosse com materiais vegetais ou mesmo com algum tipo de adobe elementar, como recentemente se observou em ambientes desta cronologia no Castelo de Gaia (RAMOS, CARVALHO, 2020: 72-7) 5 .

No interior desta estrutura, presumivelmente habitacional, foi possível identificar dois níveis de piso,

5. O que talvez justifique a apreciável quantidade de «barro de construção» recolhido nas escavações de Salreu. sobrepostos, feitos com argila cozida pelo fogo. O mais recente exibia elementos ornamentais produzidos pela impressão de uma matriz circular, porventura com raios a ligar os círculos, elemento decorativo relativamente comum, tanto em pisos, como em bases de lareira de povoados castrejos do norte do país. Entre outros, podemos elencar os paralelos, muito semelhantes, encontrados no Castro de Ovil, no vizinho concelho de Espinho (SALVADOR, SILVA, 2010: 56); no Castro de Terroso, Póvoa de Varzim (GOMES, CARNEIRO, 1999: 47; 2005: 122) ou, recentemente, no Castelo de Gaia (RAMOS, CARVALHO, 202O: 74-5), sendo por isso admissível que pudesse igualmente ter correspondido à base de uma lareira, muito desmantelada, a evidência similar de Salreu. Na verdade, na mesma área localizou-se uma pequena zona de combustão, sob a qual existia um covacho escavado num depósito argiloso natural, de função indeterminada. No Castelo de Gaia, estas bases argilosas decoradas pertenciam indubitavelmente a lareiras, aliás de grandes dimensões (RAMOS, CARVALHO, 2020: 74-5), mas já em Terroso (GOMES, CARNEIRO, 2005: 122) e numa das duas ocorrências do Castro de Ovil (SALVADOR; SILVA, 2004: 25-7), estas estruturas não eram propriamente lares mas espaços adjacentes aos mesmos, parecendo ser atribuída a Terroso a cronologia mais antiga (GOMES, CARNEIRO, ibidem), em qualquer dos casos concordes com a ocupação de Salreu.

$\mathrm{Na}$ área exterior desta cabana foi também identificado um nível de circulação, caracterizado por um nível de argila compactada. Já no talude contíguo, a noroeste, numa sanja de escavação com dois metros de largura, descobriram-se na campanha de 2011, como dissemos, tramos de dois muretes sensivelmente paralelos, construídos em momentos distintos, eventualmente relacionados com uma estrutura de delimitação e, provavelmente, de suporte de terras da plataforma, nomeadamente da área habitacional que identificámos.

\section{SECTOR K - A ESTRUTURA DE DELIMITAÇÃO}

A intervenção neste sector (Figura 4) foi despoletada pela observação, no talude marginal de um caminho, de restos construtivos, em xisto, que viriam a revelar-se parte da estrutura de delimitação do segundo talude (SILVA \& alii, 2017a: 21; ALMEIDA 
E SILVA \& alii, 2018: 40-3; SILVA; PEREIRA 202O: 220, 222),

Esta estrutura tem uma espessura que ronda os quatro metros, e é composta por pedras e terra (Figuras 5 e 6), encontrando-se relativamente mal preservada, dada a natureza litológica dos seus constituintes, sobretudo pedras de xisto de médias e pequenas dimensões, sendo o seu ligante natural a terra argilosa local. Feito no rebordo da plataforma, este muro parece ter servido, quer como meio de nivelamento e contenção de terras, quer como elemento delimitador e defensivo do espaço habitado.

Os trabalhos mais recentes permitiram concluir que o muro principal que compõe a estrutura foi edificado em alvenaria seca de xisto, apresentando orientação NO.-SE., com face voltada a SO. É composto por calhaus de xisto de médio calibre, sem ligante, tendo sido identificado numa extensão de 5,30 m, com, aproximadamente, o,80 m de largura e o,70 m de altura máxima.

$\mathrm{Na}$ base deste alinhamento foram dispostos verticalmente, com ligeira pendente para o interior, blocos de xisto de médias e grandes dimensões, com a finalidade de suportar as pedras e terras dos diferentes aterros que integram a estrutura, conferindo-lhe assim maior reforço. A construção implicou a preparação do substrato rochoso natural, que foi rebaixado e ligeiramente nivelado a fim de facilitar a construção e lhe conferir maior estabilidade e eficácia.

A estrutura foi erguida com recurso à inclusão de um conjunto de sedimentos, bem compactados, resultando numa construção escalonada, diminuindo-se assim as dificuldades inerentes ao declive apresentado pelo terreno. Sobre a rocha natural foram colocados vários depósitos para nivelar o terreno e sustentar a construção. Estes depósitos integram sedimentos, por vezes compactados por ação térmica, e abundantes blocos e lascas de xisto, de pequenas e médias dimensões. Embora não seja ainda totalmente claro, o limite interno desta estrutura parece "diluir-se» na plataforma superior, assinalando-se apenas pela presença de alguns blocos de xisto de maiores dimensões.

A escavação foi alargada à zona situada imediatamente a Este deste muro de delimitação, visando documentar eventuais vestígios de ocupação doméstica junto ao seu limite interno, mas, não obstante o assinalável volume de espólio ali recolhido, apenas foi possível reconhecer algumas estruturas dispersas e de difícil interpretação, nomeadamente, uma estrutura de combustão, cuja instalação afetou ligeiramente o limite interno da cerca.

Esta área de combustão é constituída por um pequeno covacho, preenchido por sedimentos argilosos bastante compactos, que configuraram também a sua base, entre os quais se detetou um nível, pouco espesso, de cinzas e carvões. Nas imediações, foi recolhido um volume significativo (cerca de 120 fragmentos) de uma escória esverdeada, bastante leve, assim como de alguns materiais cerâmicos com o mesmo material incrustado, evidenciando a presença de uma zona oficinal e de transformação de matéria-prima ${ }^{6}$.

Na mesma plataforma, na área afetada pela abertura do caminho que permitiu a identificação da estrutura de delimitação, observou-se um pequeno tramo de piso em argila cozida, que se encontrava compreendido entre duas outras estruturas - o embasamento de um pequeno muro e uma estrutura composta por duas lajes de xisto fincadas. Como consequência das perturbações resultantes da abertura do caminho e da abundância de raízes de árvores, não foi possível esclarecer a natureza e relação destas construções, naturalmente mais recentes do que a edificação da muralha.

\section{ESPÓLIO ARQUEOLÓGICO}

São já mais de 34600 os fragmentos cerâmicos recolhidos no Castro de Salreu, sendo este género de espólio, naturalmente, o mais comum no povoado. À cerâmica, somam-se algumas centenas de objetos em pedra, escassos metais e mais de duas dezenas de contas em pasta de vidro. Entre as recolhas artefactuais, distinguem-se alguns materiais de cronologia moderna e contemporânea, relacionados com ocupações mais recentes do povoado, como uma moeda de três reais de D. João III, do século XVI (SILVA; PEREIRA; LEMOS 2012: 79).

No que respeita à cerâmica proto-histórica do Castro de Salreu (ALMEIDA E SILVA, SILVA no prelo; SILVA, PEREIRA, LEMOS, 2012: 76-9; SILVA \& alii, 2016b: 52-3; SILVA \& alii, 2017a: 23-4; 2017b: 29-30;

\footnotetext{
6. Apesar de termos avançado a possibilidade de se tratar de uma área relacionada com a fundição de metais (ALMEIDA E SILVA \& alii, 2018: 43), as análises químicas realizadas à escória não confirmaram esta hipótese, pelo que decorrem estudos complementares a fim de melhor se compreender a presença destes elementos.
} 
ALMEIDA E SILVA \& alii, 2018: 44-7), o seu estudo, ainda em desenvolvimento, é dificultado pelo elevado grau de fragmentação das vasilhas, que reduz consideravelmente as possibilidades de análise do repertório formal (Figura 7) e das composições decorativas das peças.

No entanto, reconhece-se, entre a olaria indígena deste povoado, a maioritária presença de potes ou panelas, seguindo-se recipientes de maiores dimensões destinados a armazenamento (Figura 7, 18-23). Foram ainda detetadas formas abertas, como os vasos de asa interior e uma ou duas assadeiras retangulares, e recipientes de menores dimensões, como púcaros ou pequenos copos, formas que por vezes se apresentam munidas de asa (Figura $7, \mathrm{n}^{\circ}{ }^{17}$ ).

Quanto aos motivos decorativos, é possível identificar uma grande diversidade, tendo sido feitos com recurso às técnicas de incisão e impressão, surgindo com menos frequência a decoração plástica. Entre os motivos impressos mais comuns destacam-se os círculos concêntricos, com alguma variabilidade em termos de tamanho e de composições. As decorações surgem sobretudo nos bojos dos recipientes, havendo raros casos de impressão (círculos concêntricos) e incisão (motivo em espinha) na superfície interna, junto ao bordo. Já a decoração plástica surge apenas ocasionalmente, através da aplicação de toros e altos ou baixo relevos, sendo por vezes complementada com outras técnicas ornamentais.

No que toca à matriz constituinte das pastas argilosas, observam-se, macroscopicamente, dois fabricos mais comuns, associados a pastas areno-micáceas e a pastas micáceas. Outras produções, de menor expressão, apresentam pastas mais arenosas (associadas a recipientes de maiores dimensões); reconhecendo-se ainda outras pastas, também arenosas mas de tonalidade acinzentada, e também um grupo de vasilhas feitas com argilas mais depuradas. Como forma de validar e aprofundar estas observações tecnológicas, têm vindo a ser realizadas análises da composição química das pastas por fluorescência de raios X e microscopia eletrónica de varrimento7. Os resultados estão ainda em estudo e requerem maior volume de amostras (nomeadamente associando matérias-primas locais aos produtos manufaturados), mas uma primeira hipótese de trabalho

7. Trabalhos feitos em parceria com a TecMinho (Universidade do Minho, Guimarães), sob a direção científica do Prof. Doutor Fernando Castro. parece apontar para uma significativa identidade elementar na composição de peças indígenas com um dos grupos, de pastas mais depuradas, que sugerimos poderem corresponder a importações, eventualmente de origem meridional (SILVA, PEREIRA, LEMOS, 2012: 76; SILVA \& alii, 2016a: 86; 2017b: 32). Como elemento residual, mas relevante enquanto indicador cronológico, deve assinalar-se a presença de um ou dois fragmentos cerâmicos de ânfora, muito rolados, identificando-se nomeadamente o tipo Dressel 1, de produção itálica, correspondendo por certo à fase de abandono do povoado, nas primeiras décadas do Império (SILVA \& alii, 2017b: 32 ). Os objetos metálicos não são muito frequentes, tendo sido recolhida escória e alguns utensílios em ferro, como uma lâmina de foice e dois objetos em bronze, de cronologia proto-histórica (Figura 8, n. ${ }^{\circ} \mathrm{s}$ 3 e 4). Destes últimos, um corresponde a um possível arco de fíbula, e o outro a um pequeno objeto, talvez de adorno, com orifício, decoração em pequenos losangos na superfície externa e dois pequenos ganchos na superfície interna (SILVA, PEREIRA, LEMOS, 2012: 79-80; SILVA \& alii, 2017a: 24; ALMEIDA E SILVA \& alii, 2018: 47).

Já as contas em pasta de vidro têm aparecido cada vez com mais frequência, cifrando-se num total de 21 exemplares (Figura 8, ํㅜ 1). Apresentam diâmetros, colorações e espessura variável, sendo dominantes as de tom azul. Duas delas, apresentam um pequeno orifício onde poderá ter sido incrustado um elemento doutra coloração, podendo talvez incluir-se no leque das contas oculadas (SILVA, PEREIRA, LEMOS, 2012:79-80; SILVA \& alii, 2017a: 24; ALMEIDA E SILVA \& alii, 2018: 47).

Por fim, os objetos em pedra correspondem sobretudo a pesos (de rede, tear e cobertura) e são maioritariamente em xisto, registando-se ocasionais elementos em granito, relacionados com a moagem. Um cossoiro, um machado polido e ainda um conjunto de xistos com pequenos entalhes ou perfurações, cuja finalidade ainda não foi possível esclarecer, completam o leque desta tipologia de recolhas. Foi também identificado um pequeno núcleo em sílex, sem que por ora se reconheçam outros utensílios na mesma matéria-prima (SILVA, PEREIRA, LEMOS 2012: 79; SILVA \& alii, 2016b: 54; SILVA \& alii, 2017a: 24).

Merece nota de destaque, todavia, a presença de uma placa de xisto gravada, com motivos abstratos (Figura 9). Esta laje, fragmentada e com espessura 
bastante reduzida, é proveniente de depósitos relacionados com o derrube da muralha, no sector $\mathrm{K}$. Tem as dimensões, aproximadas, de 30 por $17 \mathrm{~cm}$, apresentando-se gravada numa das faces, com alguns motivos bastante ténues e finos, aos quais acresce um signo ramiforme, aparentemente enquadrado por uma figura subtriangular (SILVA $\mathbb{\&}$ alii, 2019: 32). O paralelo mais evidente para este objeto "artístico" parece ser o vasto conjunto de placas gravadas do povoado da Idade do Ferro do Castelinho de Cilhades, Torre de Moncorvo (SANTOS \& alii, 2012; 2016; NEVES, FIGUEIREDO, 2015), constituindo assim, aparentemente, um dos primeiros exemplos de "arte móvel» da Idade do Ferro a sul do Douro.

\section{REFLEXÕES FINAIS}

O Castro de Salreu disfrutou de uma posição geográfica particular durante a proto-história sendo, a par do Castro de Ovil (Espinho), um dos povoados mais litorais do Entre Douro e Vouga. Essa posição terá facilitado contactos com o exterior, de que serão exemplo a aparente presença de algumas cerâmicas de importação mediterrânica, assim como as diversas contas de colar em pasta de vidro, evidenciando-se talvez dois momentos distintos de conexões culturais e comerciais, um primeiro relacionado com o comércio púnico, nos séculos IV-III a.C. (SILVA, PEREIRA, 2010; PEREIRA, 2011) e outro já no quadro das primeiras importações do mundo romanizado.

O povoado estava organizado em diferentes plataformas e taludes, estando identificada no registo arqueológico pelo menos uma estrutura linear de delimitação, no segundo talude, coincidindo com os sectores A e K, que foram alvo de maior investigação. Possivelmente, uma segunda estrutura marcaria o alinhamento do terceiro talude, que apresenta grande descontinuidade topográfica, hipótese esta que não foi possível corroborar ainda no registo arqueológico. Esta estrutura multifuncional, que, embora delimitando o espaço, talvez não o fizesse na totalidade da área habitada (tanto mais que estaria articulada com os fossos), serviria certamente como elemento de contenção das plataformas ocupadas e, também, como elemento defensivo e dissuasor do acesso ao povoado.

A fragilidade das construções em xisto, nas quais era utilizado apenas ligante natural - e porventura em adobe, como admitimos - dificulta bastante a preservação dos vestígios, circunstância que associada à forte afetação negativa da florestação mecânica das últimas décadas e às significativas movimentações de terras associadas, não tem facilitado a identificação de ambientes domésticos. Ainda assim, o testemunho de uma estrutura habitacional, de planta ovalada, com marcação clara de entrada, e um piso, ou lareira, em argila decorada, constitui um dado relevante, aliás com paralelos regionais, como se viu. Conjugando a observação do espólio recolhido com as três datações de radiocarbono já efetuadas (SILVA \& alii, 2016b: 44-5) (Quadro 1), cremos que a ocupação do povoado se estenderá, talvez, desde o século IV a.C. até à mudança da Era, ou pouco tempo depois. A datação de um depósito anterior à construção habitacional identificada no sector $\mathrm{A}$ forneceu o intervalo de $358-278 \mathrm{cal} \mathrm{BC}^{8}$, concedendo assim um terminus post quem para a construção na plataforma. Já a outra datação realizada nesse sector, a partir de vestígios orgânicos carbonizados recolhidos sobre o último nível de piso, forneceu uma datação - com maior probabilidade estatística - entre 196 e $39 \mathrm{cal}$ BC, balizando assim, por agora, a ocupação daquela área do povoado entre os séculos IV e I a.C., não sendo certo, todavia, que esta data corresponda ao último momento de utilização daquela cabana. No sector $\mathrm{K}$ foi também realizada uma datação, proveniente de um depósito posterior à construção da muralha, tendo uma semente de cevada proporcionado a data de 236-111 cal BC.

Deste modo, a investigação arqueológica que vem sendo desenvolvida neste povoado, enquadrada em diferentes projetos de investigação e abrangendo também outros povoados da região do Entre Douro e Vouga, tem trazido à luz do dia informações que consideramos bastante interessantes para a compreensão do habitat, da ergologia e do povoamento proto-histórico desta área geográfica, especialmente na sua franja mais atlântica, sublinhando o desenvolvimento endógeno das comunidades, num quadro de relações diferenciadas com o exterior.

8. Utilizámos os resultados com maior probabilidade a $2 \delta$ (Quadro I). 


\section{BIBLIOGRAFIA}

ALMEIDA E SILVA, Sara; SILVA, António Manuel S. P.; PEREIRA, Gabriel; LEMOS, Paulo (2018) - Trabalhos arqueológicos no Castro de Salreu. Breve crónica da intervenção de 2018. Terras de Antuã.12. Estarreja, p. 31-49.

ALMEIDA E SILVA, Sara; SILVA, António Manuel S. P. [no prelo] - Breves considerações sobre a cerâmica da Idade do Ferro do Castro de Salreu (Estarreja, Aveiro). Atas do Congresso Internacional de Cultura Castreja. Santa Maria da Feira.

GOMES, José Flores; CARNEIRO, Deolinda (1999) -Cividade de Terroso. Póvoa de Varzim: Câmara Municipal.

GOMES, José Flores; CARNEIRO, Deolinda (2005) - Subtus Montis Terroso. Património Arqueológico no Concelho da Póvoa de Varzim. Póvoa de Varzim: Câmara Municipal.

NEVES, Dário; FIGUEIREDO, Sofia S. (2015) - Quinhentas placas gravadas da Idade do Ferro do sítio fortificado do Castelinho (Nordeste Portugal): temas figurados e padrões de distribuição. In COLLADO GIRALDO, H.; GARCÍA ARRANZ, J. (eds.) - Symbols in the Landscape: Rock Art and its Context. Proceedings of the XIX International Rock Conference IFRAO 2015. Tomar: ITM - Instituto Terra e Memória, p. 1589-1605.

PEREIRA, Gabriel R. (2011) - Dinâmicas culturais e influências meridionais no NW Peninsular: intercâmbio púnico entre os séculos VI e III a.C. Dissertação de mestrado em Arqueologia apresentada à Faculdade de Letras da Universidade do Porto.

RAMOS, Rui; CARVALHO, José (2020) - O sítio do Rei Ramiro: contributo para o conhecimento das ocupações antigas no Monte do Castelo (Vila Nova de Gaia). Apontamentos de Arqueologia e Património, 14. Em linha: http:// www.nia-era.org/publicacoes

REAL, F. Sousa (1987) - Portugal. Atlas do Ambiente. Carta Geológica (Notícia Explicativa I.12). Lisboa: Secretaria do Estado do Ambiente e Recursos Naturais.

SALVADOR, Jorge F.; SILVA, António Manuel S. P. (2004) - O Castro de Ovil e o povoamento da região de Espinho da proto-história à romanização (OVESP). Relatório Final de Trabalhos Arqueológicos. Espinho: Câmara Municipal, policopiado.

SALVADOR, Jorge F.; SILVA, António Manuel S. P. (2010) O Castro de Ovil (Espinho), um povoado da Idade do Ferro. In PINTO, F. (coord.) - Arqueologia da Terra de Santa Maria: balanços e perspectivas. Santa Maria da Feira: Liga dos Amigos da Feira, 2010, p. 53-73.

SANTOS, Filipe; SASTRE, José; FIGUEIREDO, Sofia S.; ROCHA, Fábio; PINHEIRO, Eulália; DIAS, Rodrigo (2012)- El sitio fortificado del Castelinho (Felgar, Torre de Moncorvo, Portugal). Estudio preliminar de su diacronía y las plaquetas de piedra con grabados de la Edad del Hierro. Complutum, 23 (1). Madrid, p. 165-179. http://dx.doi. org/10.5209/rev_Cmpl.2012.v23.n1.39536.
SANTOS, Filipe; PINHEIRO, Eulália; ROCHA, Fábio; SASTRE, José (2016) - O sítio e a laje 1 do Castelinho (Cilhades, Felgar, Torre de Moncorvo). Contributos para o conhecimento da II Idade do Ferro em Trás-os-Montes oriental. Estudos Pré-históricos, 18. Viseu, p. 203-217.

SILVA, António Manuel S. P. (1993) - Ocupação proto-histórica e romana no Entre-Douro-e-Vouga Litoral: Breve balanço de uma investigação em curso. Trabalhos de Antropologia e Etnologia. 33 (3-4). Porto, p. 427-443.

SILVA, António Manuel S. P. (1994) - Proto-história e Romanização no Entre Douro e Vouga Litoral. Elementos para uma avaliação crítica. Dissertação de Mestrado apresentada à Faculdade de Letras da Universidade do Porto.

SILVA, António Manuel S. P. (2002) - O Castro de Salreu um povoado indígena da Idade do Ferro. Nota arqueológica à margem de uma polémica. O Jornal de Estarreja. 4150 (22-02-2002). Estarreja, p. 3-4.

SILVA, António Manuel S. P.; PEREIRA, Gabriel R. (2010) - Povoamento proto-histórico na fachada atlântica do Entre Douro e Vouga. Paleoambientes e dinâmica cultural. In BETTENCOURT, A. M.; ALVES, M.; MONTEIRO-RODRIGUES, S. (eds.) - Variações paleoambientais e evolução antrópica no Quaternário do Ocidente Peninsular. S.l.: APEQ/CITCEM, p. 189-203.

SILVA, António Manuel S. P.; PEREIRA, Gabriel R. (2020) - Walls and Castros. Delimitation structures in the Proto-historic settlements of Entre Douro and Vouga region (Center-North of Portugal). In DELFINO, D.; COIMBRA, F. CARDOSO, D.; CRUZ, G. - Late Prehistoric Fortifications in Europe: Defensive, symbolic and territorial aspects from the Chalcolithic to the Iron Age. Proc. of the International Colloquium 'FortMetalAges', Guimarães, Portugal. Oxford: Archaeopress, p. 215-228.

SILVA, António Manuel S. P.; PEREIRA, Gabriel R.; LEMOS, Paulo A. (2012) - O castro de Salreu (Estarreja): resultados da primeira campanha de escavações arqueológicas. Terras de Antuã. 6. Estarreja, p. 47-89.

SILVA, António Manuel S. P.; PEREIRA, Gabriel R.; TAVARES, João T.; LEMOS, Paulo A.; ALMEIDA E SILVA, Sara (2016a) - Proto-história da Bacia do Antuã (2011-2015) - um projeto de investigação arqueológica em rede. Patrimónios de OAZ. o. Oliveira de Azeméis, p.77-96.

SILVA, António Manuel S. P.; PEREIRA, Gabriel; LEMOS, Paulo; ALMEIDA E SILVA, Sara (2016b) - Trabalhos arqueológicos no Crasto de Salreu, Estarreja. Breve notícia. Terras de Antuã.10. Estarreja, p. 39-57.

SILVA, António Manuel S. P.; PEREIRA, Gabriel; ALMEIDA E SILVA, Sara; LEMOS, Paulo (2017a) - Uma Aldeia de há dois mil anos. Um sítio arqueológico e a sua investigação. Terras de Antuã. 11. Estarreja, p. 15-29.

SILVA, António Manuel S. P.; PEREIRA, Gabriel; LEMOS, Paulo; ALMEIDA E SILVA, Sara (2017b) - Uma Aldeia de há 
dois mil anos. Arqueologia no Castro de Salreu. Estarreja: Câmara Municipal.

SILVA, António Manuel S. P.; PEREIRA, Gabriel; LEMOS, Paulo; ALMEIDA E SILVA, Sara [no prelo] - O Castro de Salreu (Estarreja): um povoado da Idade do Ferro nos limites meridionais da "cultura castreja". Atas do I Ciclo de Conferências do Monte Padrão. Santo Tirso.

SILVA, António Manuel S. P.; SÁ, Edite Martins de; SALVADOR; Jorge Fernando; LEMOS, Paulo André P.; ALMEIDA E SILVA, Sara (2019) - O Castro de Salreu, um dos povoados proto-históricos atlânticos do Entre Douro e Vouga. Terras de Antuã. 13. Estarreja, p. 24-44.
SILVA, Armando C. F. (1986) - A Cultura Castreja no Noroeste de Portugal. Paços de Ferreira: Câmara Municipal; Museu Arqueológico da Citânia de Sanfins.

TEIXEIRA, Carlos (1963) - Carta Geológica de Portugal na escalade1/50.ooo.Notícia Explicativada Folha13-C(OVAR). Lisboa: Direcção-Geral de Minas e Serviços Geológicos de Portugal.

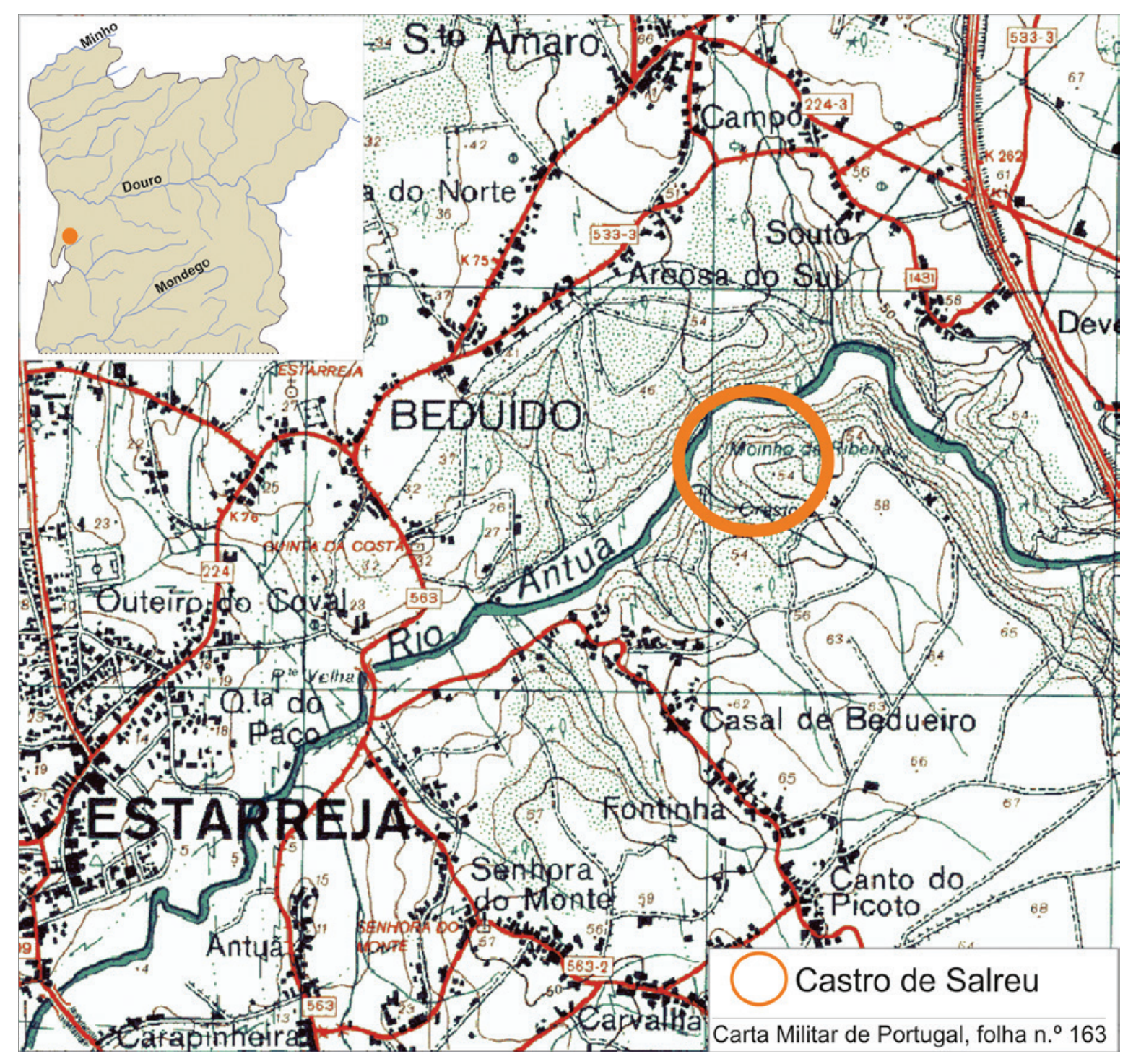

Figura 1 - Localização do Castro de Salreu. 


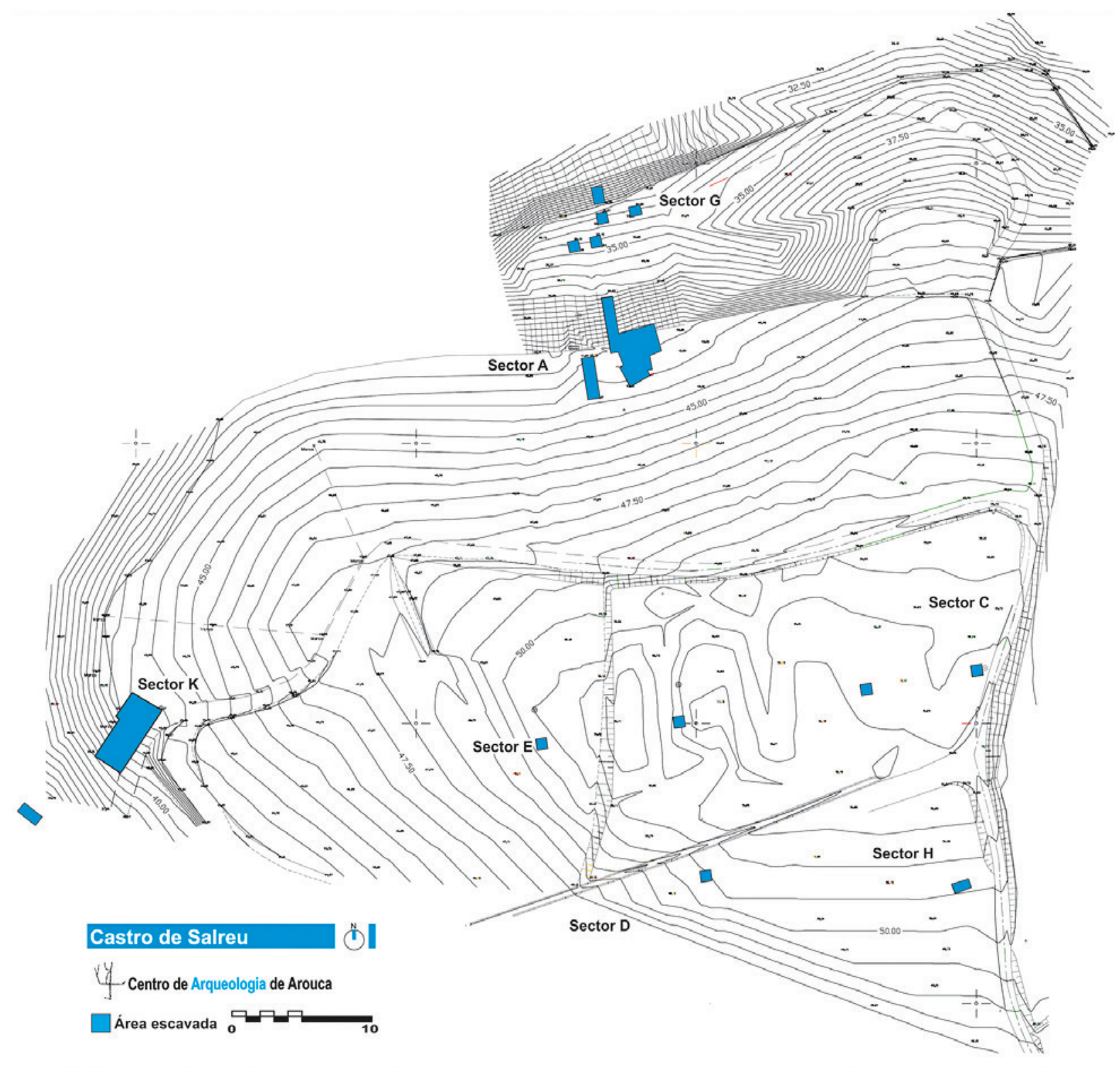

Figura 2 - Levantamento topográfico do Castro de Salreu, com implantação das áreas intervencionadas (C.M. Estarreja/Multimapa). 


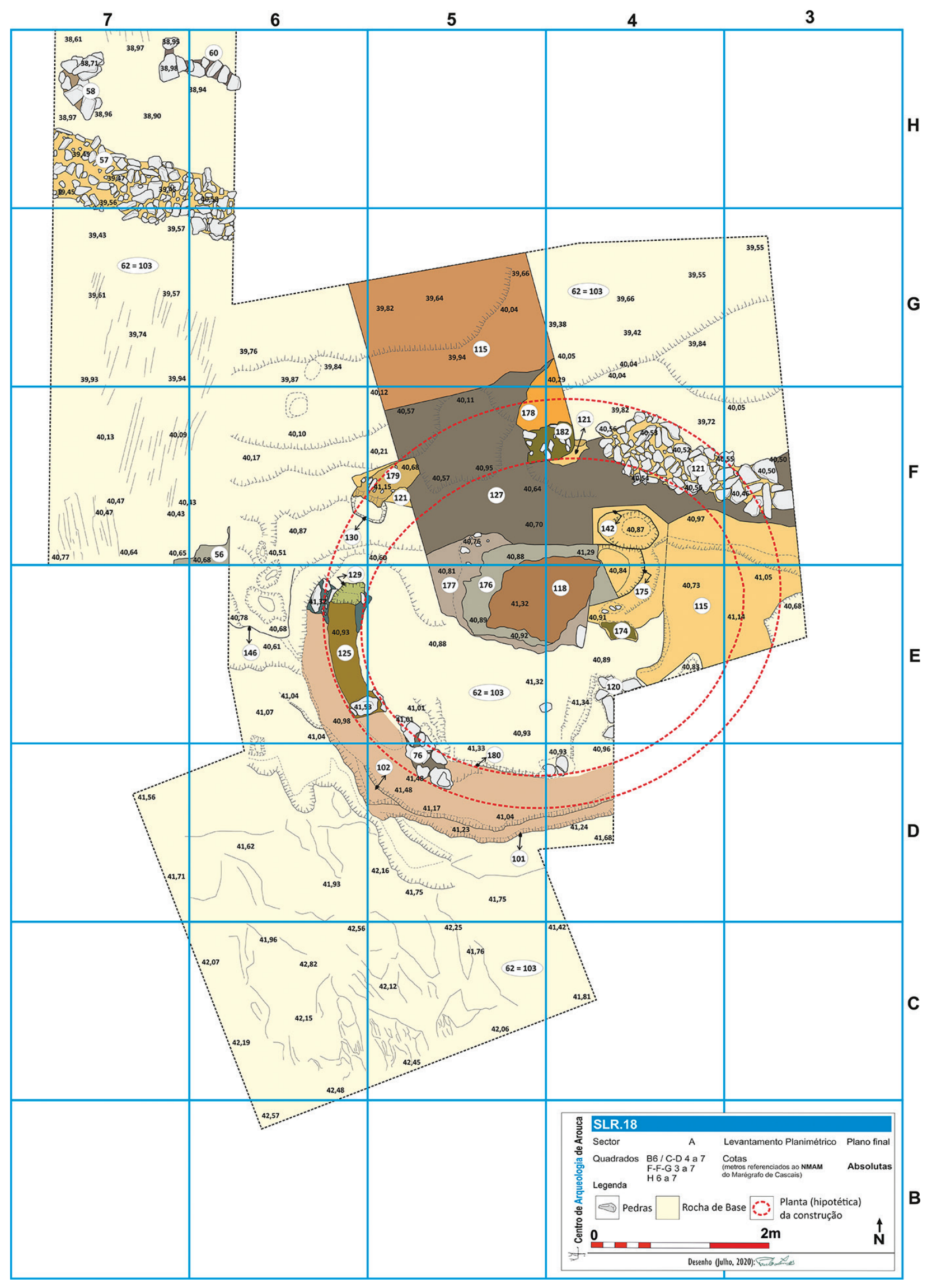

Figura 3 - Plano Final do Sector A, observando-se a base da estrutura doméstica. 


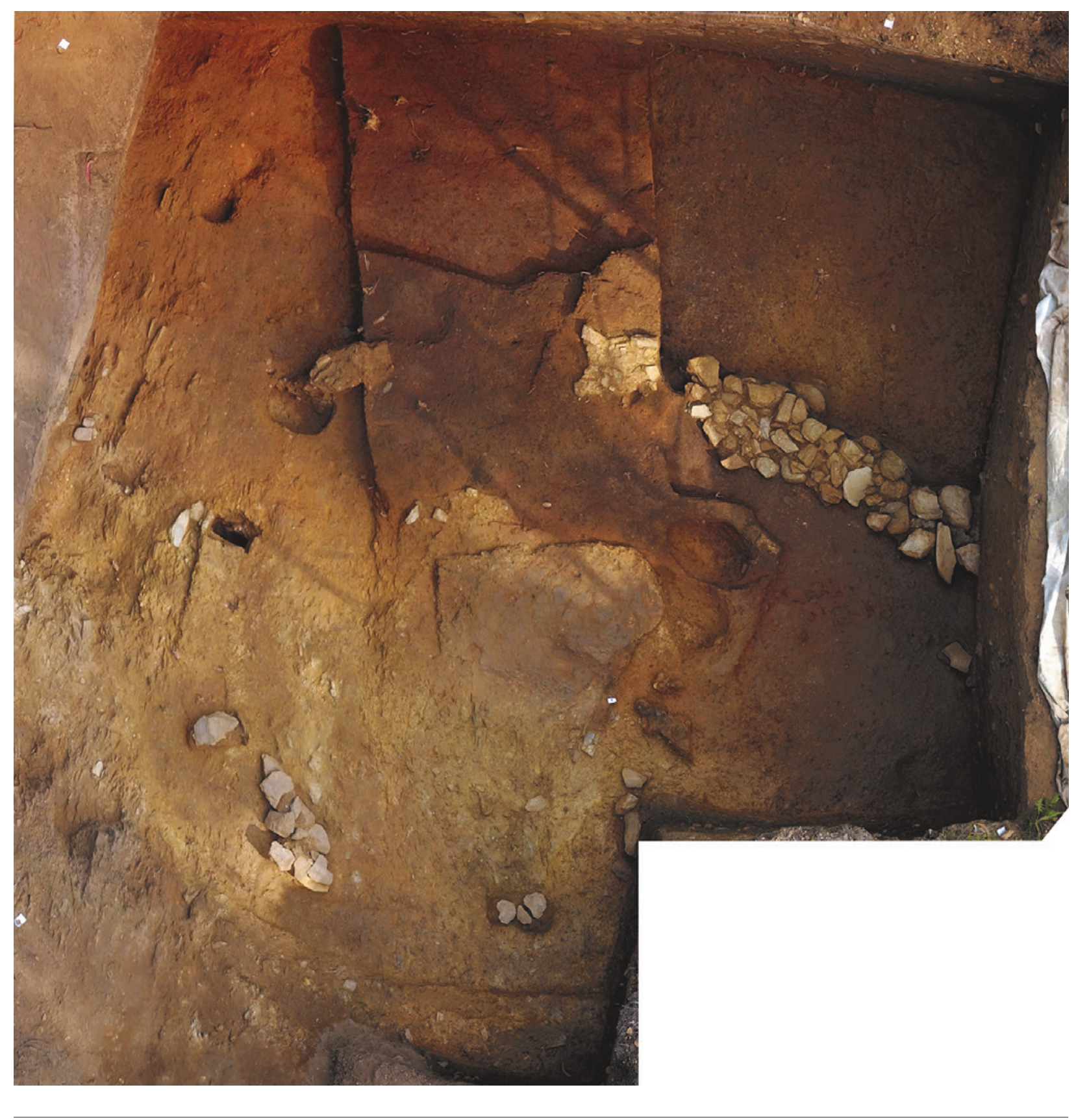

Figura 4 - Fotografia aérea do sector A (2018). Foto: Multimapa. 


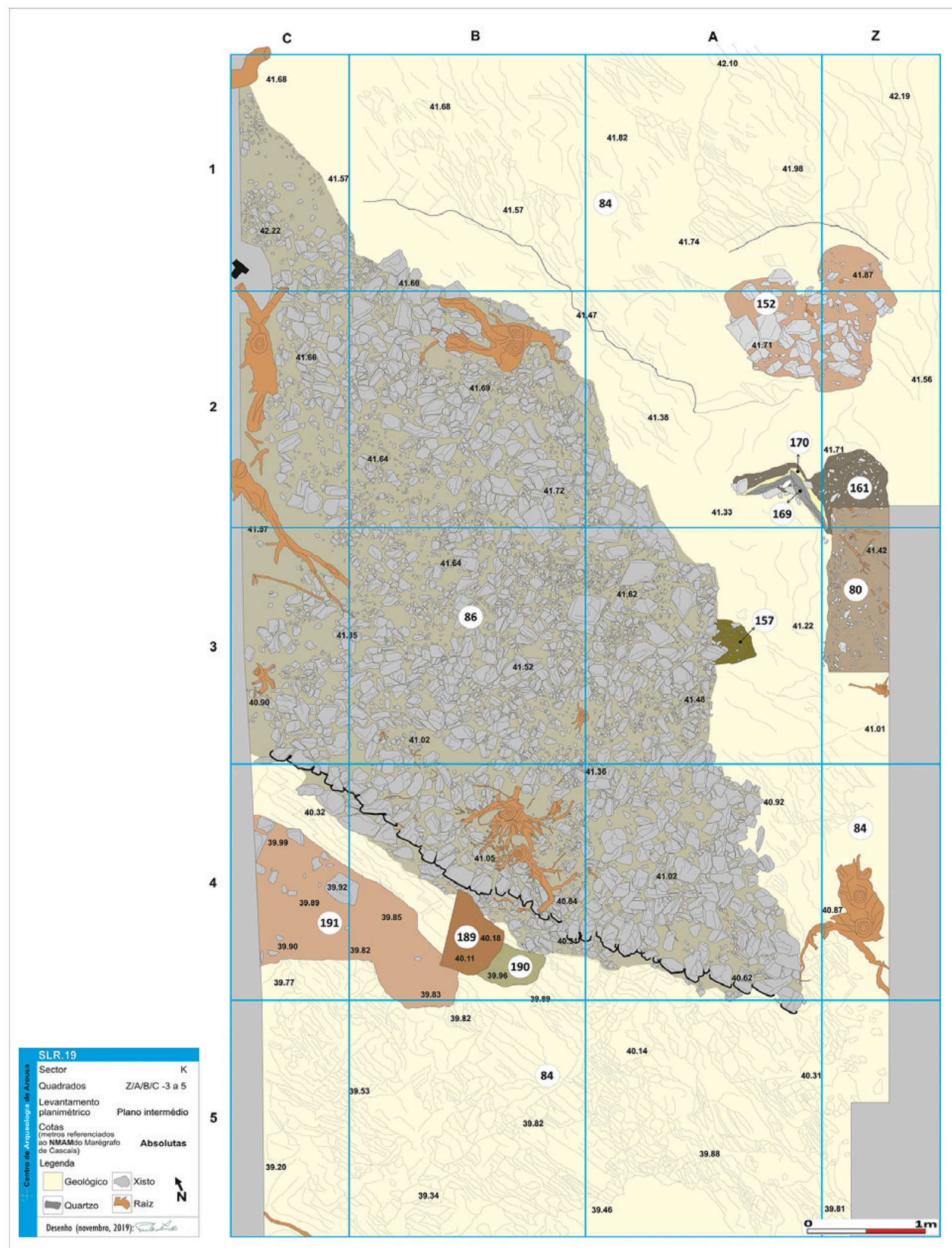

Figura 5 - Plano Final (2019) do Sector K, com o troço da estrutura de delimitação do povoado. 


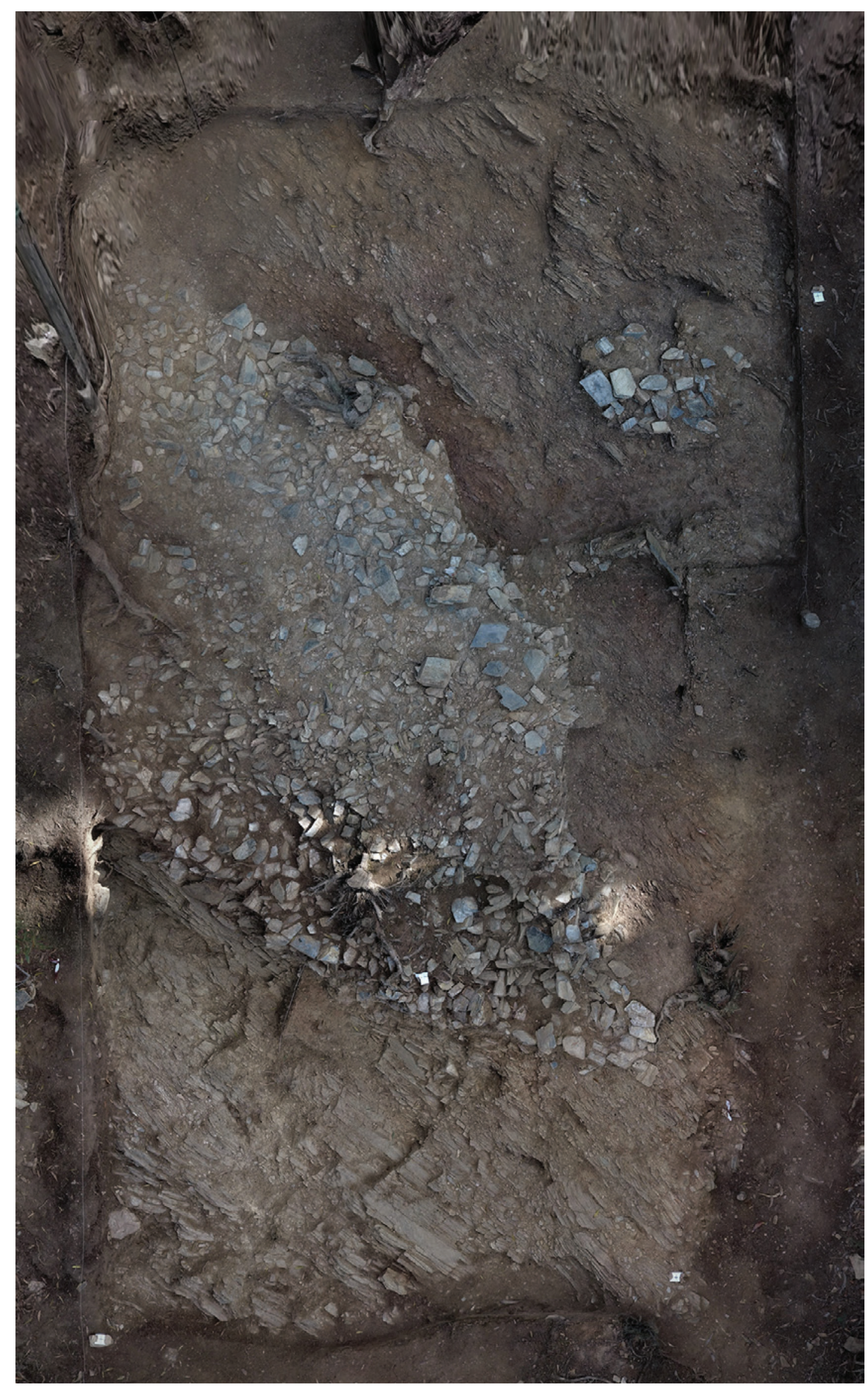

Figura 6 - Vista aérea do Sector K (2019). Foto: Multimapa. 


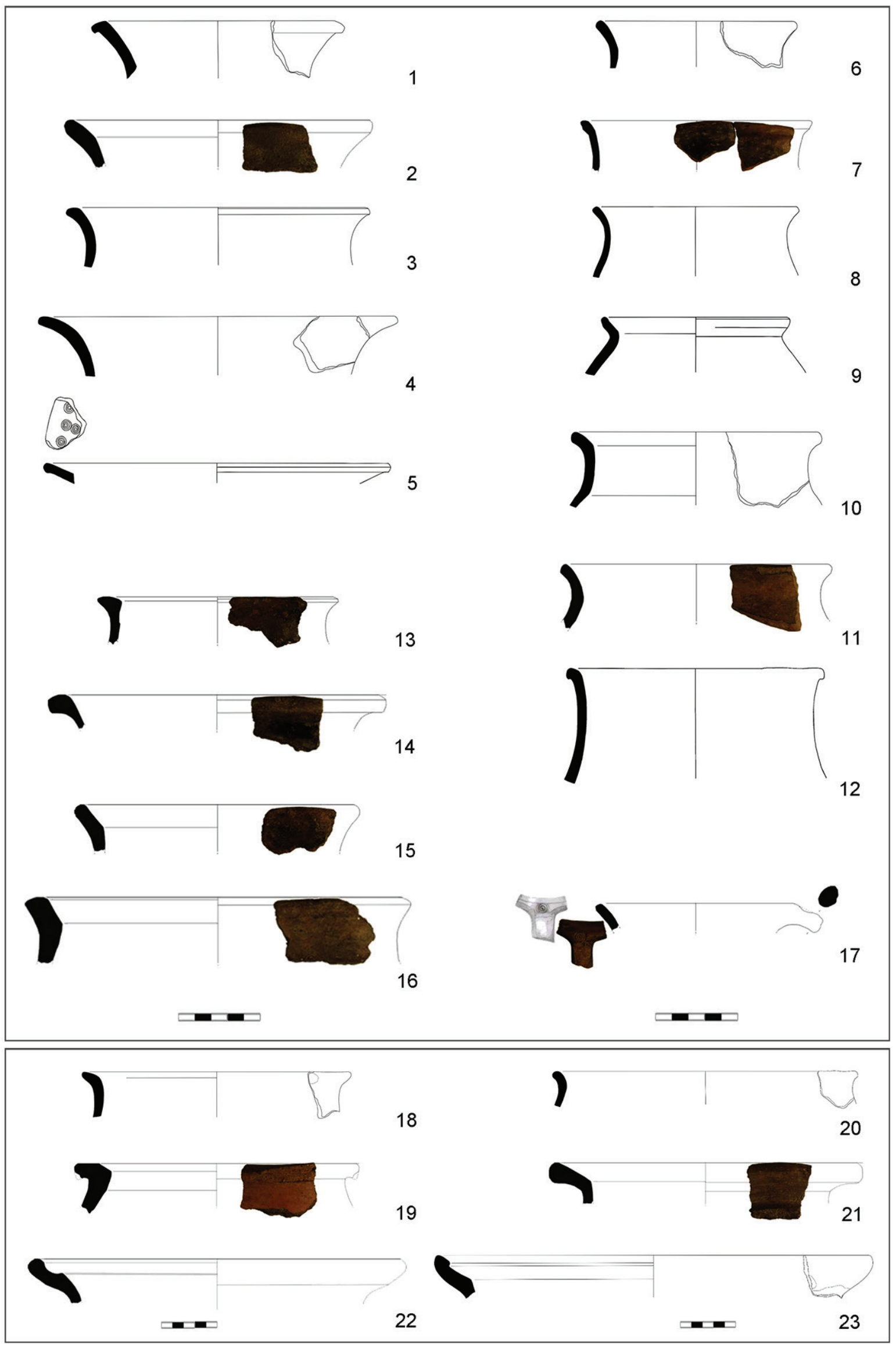

Figura 7 - Principais formas identificadas na cerâmica proto-histórica de Salreu. 


\section{O
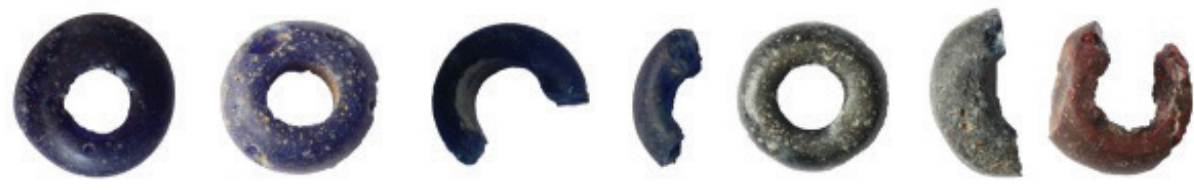 .

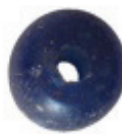 \\ ○ 0 \\ 000000

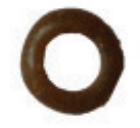

1
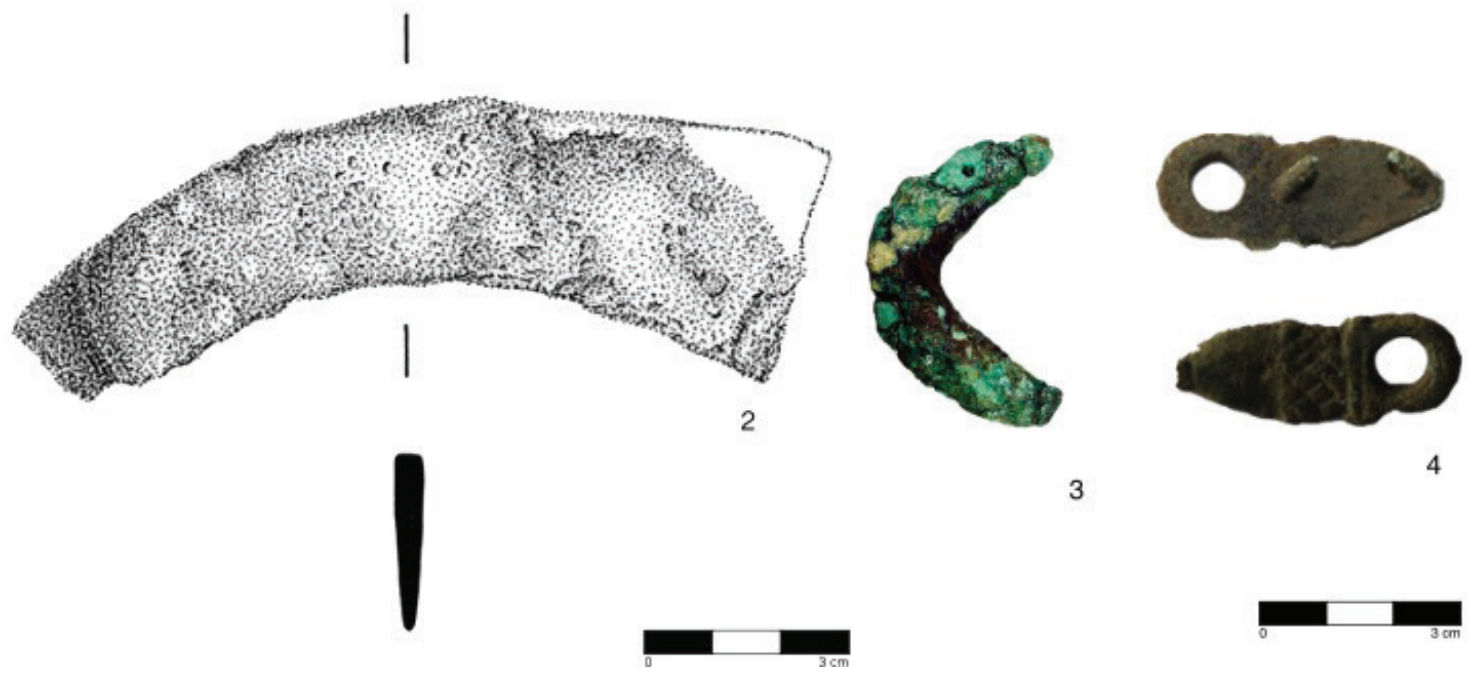

4

Figura 8 - Material não cerâmico do Castro de Salreu: Contas de colar em pasta de vidro e objetos metálicos (Desenho 2: Amélia Mendes/MDDS; Foto 3: Manuel Santos/MDDS).

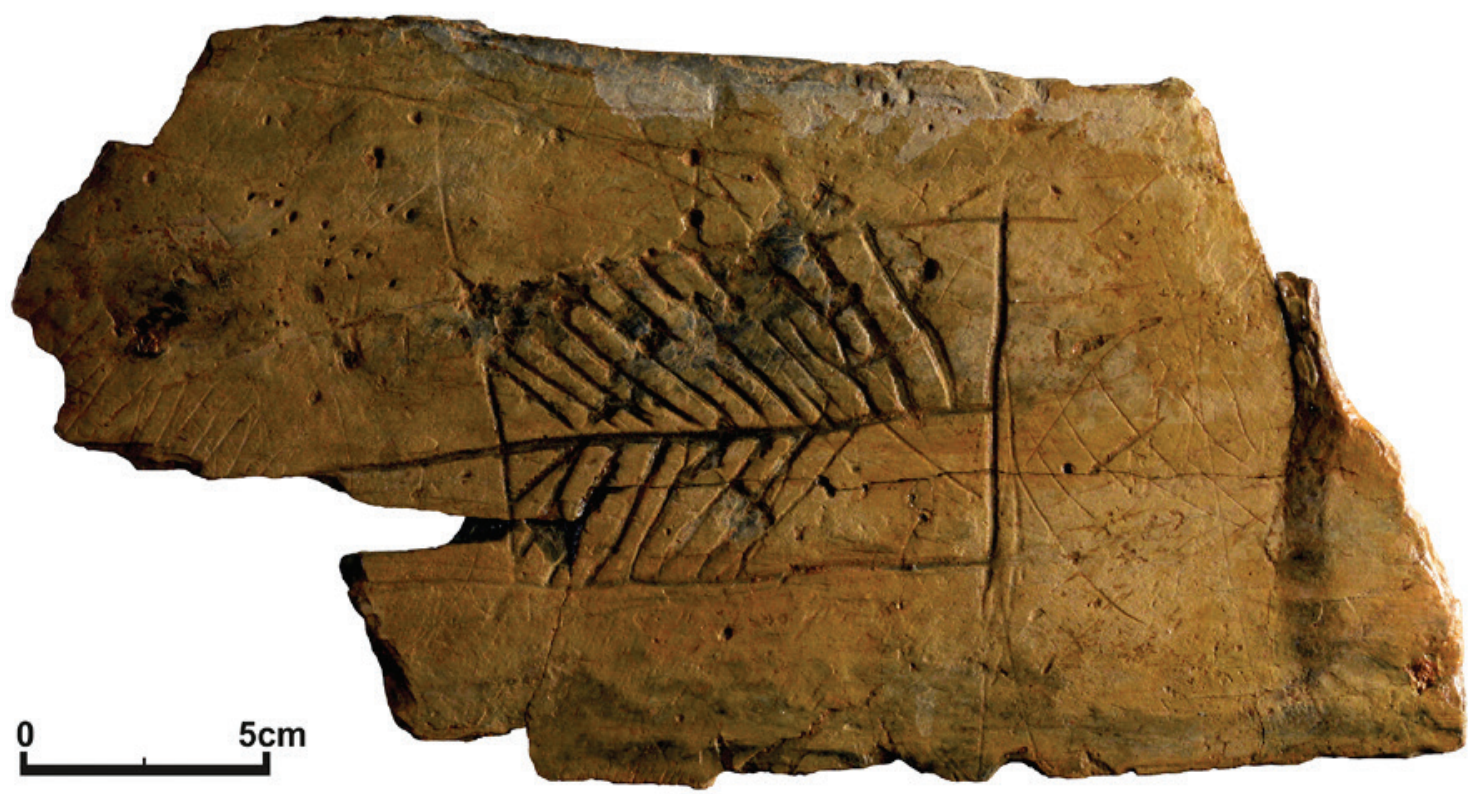

Figura 9 - Placa de xisto gravada. Fotografia: Manuel Santos/MDDS. 


\begin{tabular}{|c|c|c|c|c|c|c|c|c|c|c|c|c|c|}
\hline \multirow{3}{*}{ № Lab } & \multirow{3}{*}{ Contexto } & \multirow{3}{*}{ Material } & \multirow{3}{*}{\begin{tabular}{l|}
$o(13 \mathrm{C})$ \\
per mil
\end{tabular}} & \multicolumn{2}{|c|}{$\begin{array}{c}\text { Fraction of } \\
\text { modern }\end{array}$} & \multirow{3}{*}{ BP } & \multirow{3}{*}{1 sigma } & \multicolumn{2}{|c|}{ OXCAL $4.2[1]$} & \multicolumn{3}{|c|}{ Calib Rev 7.0.4 [2] } & \multirow{3}{*}{\begin{tabular}{|c}
$\begin{array}{c}\text { CalPal_2007_ } \\
\text { HULU [3] }\end{array}$ \\
$\begin{array}{c}\text { Calendric Age } \\
\text { Cal BP }\end{array}$ \\
$68 \%$
\end{tabular}} \\
\hline & & & & \multirow{2}{*}{ pMC } & \multirow{2}{*}{\begin{tabular}{|c|}
10 \\
error
\end{tabular} \mid} & & & $1 \sigma$ & $2 \sigma$ & $1 \sigma$ & $2 \sigma$ & \multirow{2}{*}{$\begin{array}{l}\text { Probab. } \\
\text { Mediana }\end{array}$} & \\
\hline & & & & & & & & $68.2 \%$ probability & $95.4 \%$ probability & $68.3 \%$ probability & 95.4\% probability & & \\
\hline \multirow{3}{*}{$\begin{array}{l}\text { D-AMS } \\
8678\end{array}$} & \multirow{3}{*}{$\begin{array}{l}\text { Sect A-Sd } \\
1-\text { UE 0S1 }\end{array}$} & \multirow{3}{*}{$\begin{array}{l}\text { Sementes } \\
\text { fovaceoe }\end{array}$} & \multirow{3}{*}{-25.1} & \multirow{3}{*}{76.22} & \multirow{3}{*}{0.22} & \multirow{3}{*}{2181} & \multirow{3}{*}{23} & $352 B C(50.7 \%) 2968 C$ & $3588 \mathrm{C}(57.5 \%) 278 \mathrm{BC}$ & $352 \mathrm{BC}(73.0 \%) 295 \mathrm{BC}$ & $3588 \mathrm{BC}(60.2 \%) 278 \mathrm{BC}$ & \multirow{3}{*}{-300} & \multirow{3}{*}{$275 \pm 66$} \\
\hline & & & & & & & & $228 B C(05.7 \%) 220 B C$ & $259 \mathrm{BC}(37.96) 174 \mathrm{BC}$ & $229 \mathrm{BC}(08.9 \%) 220 \mathrm{BC}$ & 250051208001708 & & \\
\hline & & & & & & & & $2128 \mathrm{C}(11.8 \%) 198 \mathrm{BC}$ & & $2128 \mathrm{C}(18.1 \%) 1978 \mathrm{C}$ & & & \\
\hline \multirow{2}{*}{$\begin{array}{l}\text { D-AMS } \\
033461\end{array}$} & \multirow{2}{*}{$\begin{array}{l}\text { Sect. A } \\
\text { UE E118 } \\
\text { (piso) }\end{array}$} & \multirow{2}{*}{$\begin{array}{c}\text { Carvão Erica } \\
\text { scoporia } \\
\text { /umbelloto }\end{array}$} & \multirow{2}{*}{ n.i. } & \multirow{2}{*}{77.13} & \multirow{2}{*}{0.30} & \multirow{2}{*}{2086} & \multirow{2}{*}{31} & $118 B C(95.4 \%) 408 C$ & \multirow{2}{*}{$196(95.4 \%)$ 40BC } & $118 \mathrm{BC}(69.6 \%) 548 \mathrm{BC}$ & $196 \mathrm{BC}(99.9 \%) 39 \mathrm{BC}$ & \multirow{2}{*}{-109} & \multirow{2}{*}{$113 \pm 45$} \\
\hline & & & & & & & & $160 \mathrm{BC}(20.9 \%) 131 \mathrm{BC}$ & & $160 \mathrm{BC}(30.4 \%) 1318 \mathrm{CC}$ & $78 \mathrm{BC}(0.1 \%) 5 \mathrm{BC}$ & & \\
\hline \multirow{3}{*}{$\begin{array}{l}\text { D-AMS } \\
033463\end{array}$} & \multirow{3}{*}{$\begin{array}{l}\text { Sect. K } \\
\text { UE } 116\end{array}$} & \multirow{3}{*}{$\begin{array}{c}\text { Sementes } \\
\text { Hordeum } \\
\text { vulgare }\end{array}$} & & & & & & $350 \mathrm{BC}(34.7 \%) 303 \mathrm{BC}$ & $236 \mathrm{BC}(51,5 \%) 111 \mathrm{BC}$ & $350 \mathrm{BC}(50.1 \%) 305 \mathrm{BC}$ & $235 B C(48.5 \%) \quad 1478 C$ & & \\
\hline & & & n.i. & 76.41 & \begin{tabular}{|l|} 
\\
\end{tabular} .26 & 2161 & 27 & & $358 \mathrm{BC}(42.2 \%) 281 \mathrm{BC}$ & & $3578 \mathrm{C}(44.3 \%) 282 \mathrm{BC}$ & .224 & $259 \pm 77$ \\
\hline & & & & & & & & $210 \mathrm{BC}(33.5 \%) 169 \mathrm{BC}$ & $258 B C(01.6 \%) 2448 \mathrm{C}$ & $209 \mathrm{BC}(49.9 \%) 170 \mathrm{BC}$ & $\begin{array}{c}144 \mathrm{BC}(05.8 \%) 111 \mathrm{BC} \\
257(01.4 \%) 245 \mathrm{BC}\end{array}$ & & \\
\hline
\end{tabular}

[1] OxCal v4.2.4 Bronk Ramsey (2013); r.5; IntCal13 atmospheric curve (Reimer et al 2013); OxCal v4.2.4 Bronk Ramsey (2013); r.5

[2] RADIOCARBON CALIBRATION PROGRAM". CALIB REV7.1.0. Copyright 1986-2018 M Stuiver and PJ Reimer, "To be used in conjunction with: Stuiver, M., and Reimer, PJ., 1993, Radiocarbon, 35, 215-230. Reimer PJ, Bard E, Bayliss A, Beck IW, Blackwell PG, Bronk Ramsey C, Buck CE, Cheng H, Edwards RL, Friedrich M, Grootes PM, Guilderson TP, Haflidason H, Hajdas I, Hatté C, Heaton TI, Hogg AG, Hughen Ka, Kaiser KF, Kromer B, Manning SW, Niu M, Reimer RW, Richards DA, Scott [3] quickcal2007 ver.1.5. Monrepos. Archäologisches forschungszentrum und Museum für menschliche Verhaltensevolution. http://www.calpal-online.de

n.i. - năo indicado

Quadro I - Datações radiocarbónicas do Castro de Salreu. 



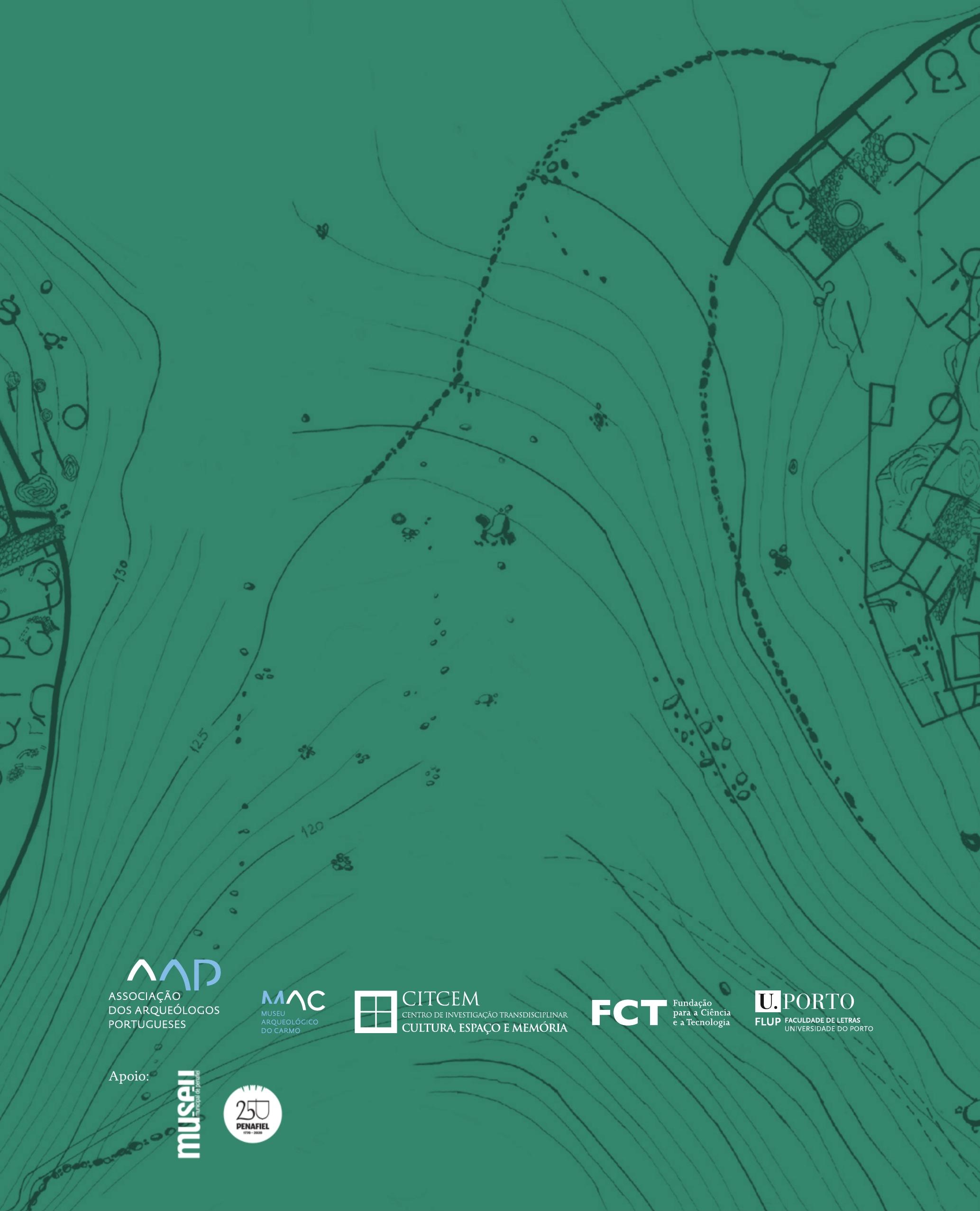

